\title{
High resolution climate and vegetation simulations of the Late Pliocene, a model-data comparison over western Europe and the Mediterranean region
}

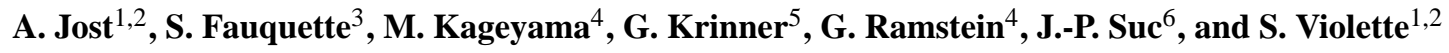 \\ ${ }^{1}$ UPMC Univ. Paris 06, UMR 7619, Sisyphe, France \\ ${ }^{2}$ CNRS, UMR 7619, Sisyphe, France \\ ${ }^{3}$ Univ. Montpellier 2, UMR CNRS 5554, Institut des Sciences de l'Evolution, France \\ ${ }^{4}$ UMR CEA-CNRS-UVSQ 1572, Laboratoire des Sciences du Climat et de l'Environnement/IPSL, France \\ ${ }^{5}$ UJF Univ. Grenoble 1, UMR CNRS 5183, Laboratoire de Glaciologie et Géophysique de l'Environnement, France \\ ${ }^{6}$ UCB Univ. Lyon 1, UMR CNRS 5125, Laboratoire PaléoEnvironnements et PaléobioSphère, France
}

Received: 9 April 2009 - Published in Clim. Past Discuss.: 13 May 2009

Revised: 31 August 2009 - Accepted: 15 September 2009 - Published: 12 October 2009

\begin{abstract}
Here we perform a detailed comparison between climate model results and climate reconstructions in western Europe and the Mediterranean area for the mid-Piacenzian warm interval ( $c a 3 \mathrm{Myr}$ ago) of the Late Pliocene epoch. This region is particularly well suited for such a comparison as several quantitative climate estimates from local pollen records are available. They show evidence for temperatures significantly warmer than today over the whole area, mean annual precipitation higher in northwestern Europe and equivalent to modern values in its southwestern part. To improve our comparison, we have performed high resolution simulations of the mid-Piacenzian climate using the LMDz atmospheric general circulation model (AGCM) with a stretched grid which allows a finer resolution over Europe. In a first step, we applied the PRISM2 (Pliocene Research, Interpretation, and Synoptic Mapping) boundary conditions except that we used modern terrestrial vegetation. Second, we simulated the vegetation for this period by forcing the ORCHIDEE (Organizing Carbon and Hydrology in Dynamic Ecosystems) dynamic global vegetation model (DGVM) with the climatic outputs from the AGCM. We then supplied this simulated terrestrial vegetation cover as an additional boundary condition in a second AGCM run. This gives us the opportunity to investigate the model's sensitivity to the simulated vegetation changes in a global warming context.
\end{abstract}

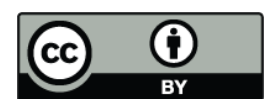

Correspondence to: A. Jost

(anne.jost@upmc.fr)
Model results and data show a great consistency for mean annual temperatures, indicating increases by up to $4^{\circ} \mathrm{C}$ in the study area, and some disparities, in particular in the northern Mediterranean sector, as regards winter and summer temperatures. Similar continental mean annual precipitation and moisture patterns are predicted by the model, which broadly underestimates the wetter conditions indicated by the data in northwestern Europe. The biogeophysical effects due to the changes in vegetation simulated by ORCHIDEE are weak, both in terms of the hydrological cycle and of the temperatures, at the regional scale of the European and Mediterranean mid-latitudes. In particular, they do not contribute to improve the model-data comparison. Their main influence concerns seasonal temperatures, with a decrease of the temperatures of the warmest month, and an overall reduction of the intensity of the continental hydrological cycle.

\section{Introduction}

Past well-documented episodes of significant climate warming provide climate change scenarios that can help us to test the sensitivity of physical models of the climate system and to evaluate the significance of their results in the context of future climate change prediction. It is necessary to look back to the Late Pliocene, within the middle part of the Piacenzian stage, to find the last notable and stable phase of global warmth, considered as the closest potential analogue of the expected near future climate state (Jansen et al., 2007). Indeed, the warming that occurred between around 3.3 and

Published by Copernicus Publications on behalf of the European Geosciences Union. 
3 million years before present is the most recent interval in geological history during which a significantly warmer-thanpresent global climate was maintained over a period longer than any interglacial stage of the Quaternary (Dowsett et al., 1996) in an almost similar to present geographic configuration (Crowley, 1996). A large number of modelling studies (e.g. Chandler et al., 1994; Sloan et al., 1996; Haywood et al., 2000a; Haywood and Valdes, 2004; Jiang et al., 2005) suggests that global average temperatures were approximately 2 to $3^{\circ} \mathrm{C}$ greater than today, i.e. a level of warming within the range of projected global temperature increase for the mid to late 21st century (Meehl et al., 2007). Atmospheric concentrations of carbon dioxide (estimated to be between 360 and 400 ppmv, Kürschner et al., 1996; Raymo et al., 1996) are also comparable to what could occur during the 21 st century. The mid-Piacenzian, which itself contains episodic climate fluctuations, takes place at the transition from relatively warm stable global climate conditions to the significant global cooling of the Pleistocene, just before the initiation of the Northern Hemisphere major glaciations, approximately 2.7 million years ago (Leroy et al., 1998; Zachos et al., 2001; St. John and Krissek, 2002). The causes of the mid-Piacenzian optimum remain uncertain. A combination of increased levels of greenhouse gases in the atmosphere and an enhanced meridional ocean heat transport has been proposed as a leading explanation (e.g. Crowley, 1996; Dowsett et al., 1996; Raymo et al., 1996). Potential causes such as orographic effects related to an altered elevation of major mountain chains (Rind and Chandler, 1991), ice-albedo feedbacks relationships resulting from a reduced extent of high-latitude terrestrial ice sheets and sea-ice cover (Haywood and Valdes, 2004) or permanent El Niño-like conditions (e.g. Molnar and Cane, 2002) have also been invoked.

The mid-Piacenzian therefore appears a very interesting period to study given the predictions of future global warming. Climate modelling can help determining the causes of the warming. This period, also referred to as PRISM Time Slab or PRISM Interval, has been selected for detailed study and is reasonably well-documented through both marine and terrestrial proxy climate records (e.g. Dowsett and Cronin, 1991; Poore and Sloan, 1996) that have allowed the reconstruction of comprehensive global datasets, all of which are suitable for integration into GCMs (PRISM2, Dowsett et al., 1999; Dowsett, 2007). Indeed, many simulations have been performed to investigate the nature and variability of climate during the mid-Piacenzian, from the examination of the global response of atmosphere(-ocean) general circulation models $(\mathrm{A}(\mathrm{O}) \mathrm{GCMs})$ (GISS, NCAR GENESIS, UKMO, IAP AGCMs and HadCM3 AOGCM) to such boundary conditions (Chandler et al., 1994; Sloan et al., 1996; Haywood et al., 2000a; Haywood and Valdes, 2004) to the evaluation on regional scale climate changes (Haywood et al., 2000b, 2001; Jiang et al., 2005). Various sensitivity analyses have been performed to explore the potential causes for the Late Pliocene warmth (e.g. Haywood et al.,
2007; Lunt et al., 2008). Following current extensive research efforts to understand climate-vegetation interactions (Cosgrove et al., 2002, and references therein), several of the latest studies have considered the climatic impact of the midPiacenzian vegetation cover. Even though its influence on global climate appears to be rather minor, the authors show that it must be considered on a regional scale at mid to high latitudes (Jiang et al., 2005), especially in the regions encountering the most prominent changes of vegetation, e.g. in the polar and subpolar regions (Salzmann et al., 2009; Lunt et al., 2009). It can affect the seasonality of temperatures over wide regions (Haywood and Valdes, 2006).

Within this framework, our objective is to perform such an analysis of model sensitivity to vegetation changes, through the use of a combined data and modelling approach, centred on western Europe and the Mediterranean region as a well-documented case study. Indeed, the existence of reconstructions of the mid-Piacenzian climate based on palynological analyses provides a detailed quantification of the main climatic variables of the period and a reliable description of the vegetation of this region at time of global warming (Fauquette et al., 1998b, 2007). We rely on these terrestrial paleoclimate archives to examine the performance of the atmospheric general circulation model LMDz in simulating the mid-Piacenzian climate, mainly in terms of temperatures and precipitation. This AGCM uses a stretched grid, which allows for a finer resolution over Europe. This gives us the opportunity to refine our comparison between model results and climate reconstructions from local pollen data and to investigate specific regional aspects of the Late Pliocene paleoclimate response of western European and Mediterranean regions. Moreover, running the climate model at high resolution allows to improve orographic resolution and representation of dynamical and physical processes acting at small scales and hence, to reproduce precipitation pattern with a better accuracy (Jost et al., 2005), especially close to the main orographic features, the Alps and the Pyrenees in our case study. High resolution is more particularly essential for the description of the Mediterranean climate, which is strongly driven by local processes induced by the complex orography of this region (Li et al., 2006).

Our experimental design also accounts for the influence of the mid-Piacenzian vegetation on the climate. Indeed, we simulate the vegetation for this period by forcing the DGVM ORCHIDEE (Krinner et al., 2005) with the climatic outputs from our first AGCM run, which uses a modern vegetation cover. We then supply this simulated vegetation coverage as an additional boundary condition in a second AGCM run, as a first step of including the vegetation feedback into an atmospheric-vegetation fully coupled simulation design. The numerical experiments are therefore designed to investigate vegetation distributions during the mid-Piacenzian and to explore in detail the sensitivity of the climate model results to different representations of the land cover. We examine the consistency between the vegetation cover produced by 
the vegetation model and palynological paleodata. We discuss the accuracy of the resulting simulated climate for the mid-Piacenzian by comparing the second experiment to the first one and their fit to the paleoclimatic reconstructions.

\section{Experimental design}

We employ the high resolution version LMDZ.3.3 of the Laboratoire de Météorologie Dynamique atmospheric model (Zhou and Li, 2002; Li and Conil, 2003), which is part of the Institut Pierre Simon Laplace (IPSL) atmosphere-oceanvegetation coupled GCM (Marti et al., 2005). We use a stretched grid with a horizontal resolution down to about $60 \mathrm{~km}$ near the centre of the zoom, centred on Paris. In previous works, this configuration has been evaluated for the present-day climate state (Jost et al., 2005) and has already been used to explore the Last Glacial Maximum, the Heinrich Events 1 and 4 paleoclimates (Jost et al., 2005; Kageyama et al., 2005; Sepulchre et al., 2007, respectively). The model is formulated in the finite-difference grid with 144 points in longitude, 108 points in latitude and 19 hybrid vertical layers. The physical parameterizations of this version are described in detail in Marti et al. (2005). On the continent, the land surface scheme ORCHIDEE (Krinner et al., 2005) is coupled to the atmospheric model. Only the thermodynamic component of ORCHIDEE is active in the simulations presented here.

First, two numerical experiments have been carried out, the first for the modern period, referred to as CTRL, and which is the same as in Jost et al. (2005) in which Atmospheric Model Intercomparison Project (AMIP) monthly mean sea surface temperatures (SSTs) and sea ice extent boundary conditions were prescribed (Taylor et al., 2001), the second corresponding to PRISM Time Slab conditions. The climatological averages were computed from the last ten years of each 11-year run.

All numerical simulations are forced by the present-day orbital configuration. Atmospheric $\mathrm{CO}_{2}$ and $\mathrm{CH}_{4}$ concentrations are set to values of $315 \mathrm{ppmv}$ and $790 \mathrm{ppbv}$ respectively, following the experimental design defined in the mid-Piacenzian climate simulations using atmosphere-only GCMs (Chandler et al., 1994; Sloan et al., 1996; Haywood et al., 2000a; Jiang et al., 2005; Haywood et al., 2009). Therefore, the impacts arising from the increase in atmospheric $\mathrm{CO}_{2}$ (absolute level of around $400 \mathrm{ppmv}$ ) occurring during the mid-Piacenzian, as indicated by proxy estimates (Kürschner et al., 1996; Raymo et al., 1996), are not taken into account in this study. However, the 400 ppmv value, which is used in ocean-atmosphere or vegetation-atmosphere coupled experiments (e.g. Haywood and Valdes, 2004, 2006, respectively), is not completely consensual for $3 \mathrm{Ma}$. First the error bar is large whatever the proxy used (Kürschner et al., 1996; Raymo et al., 1996). Second the mean value itself is often lower than 400 ppmv (Kürschner et al., 1996; Pearson and Palmer, 2000; Zachos et al., 2008).
The prescribed boundary conditions for the midPiacenzian are applied according to the PRISM2 reconstruction (Dowsett et al., 1999; Dowsett, 2007) compiled by the United States Geological Survey's Pliocene Research, Interpretation and Synoptic Mapping group, covering the timeslab between 3.29 and $2.97 \mathrm{MaBP}$ (geomagnetic polarity time scale of Berggren et al., 1995). This global synthesis of the paleoenvironmental and paleoclimatic conditions of the middle part of the Piazencian stage of the Pliocene epoch consists of a $2^{\circ} \times 2^{\circ}$ digital data set that derives from a series of studies conducted at a large number of marine and terrestrial sites and areas (e.g. Cronin, 1991; Dowsett et al., 1992, 1994, 1996; Poore and Sloan, 1996; Williams et al., 2005). It is the most complete and detailed global reconstruction of climate and environmental conditions for any warm period prior to the last thousands of years. A detailed description of the PRISM2 data set and how it was created can be found in Dowsett et al. (1999); Dowsett (2007). PRISM Time Slab surface conditions involve, with respect to the present configuration (Fig. 1):

1. $a+25 \mathrm{~m}$ sea-level rise leading to slightly modified coastlines;

2. a substantial reduction of ice-sheets size and height (by $50 \%$ for Greenland and by 33\% for Antarctica) and of sea-ice, the Arctic being seasonally ice free;

3. an altered orography, e.g. a reduced elevation of major mountain chains, such as the Rockies Mountains and the Andes Cordillera, related to Late Cenozoic uplift, and in Greenland and Antarctica, due to removal of continental ice, and a higher East African Rift System;

4. increased SSTs at middle to high latitudes, especially in the northeastern North Atlantic sector, but unchanged SSTs in low latitudes;

5. and the presence of warmth- or moisture-loving vegetation at middle to high latitudes.

As stated in the introduction, previous modelling studies have emphasized the role of warmer sea surface temperatures and reduced land and sea ice extent, as specified by the PRISM2 data set, in determining the mid-Piacenzian climate (Haywood and Valdes, 2004; Jiang et al., 2005). Paleogeographic change has also been invoked as a major contributing mechanism to global Late Pliocene warmth (Rind and Chandler, 1991). In this respect, it is certainly crucial for mid-Piacenzian climate modelling to describe the surface relief with accuracy because of significant orographic changes, mainly due to Cenozoic tectonics. In the European and Mediterranean areas, the Alpine tectonics must be responsible for elevation differences. However, the mid-Piacenzian relief is poorly known in detail, the PRISM2 reconstruction being only a first order estimate of the mid-Piacenzian orography derived from present day elevations. Therefore, in the 

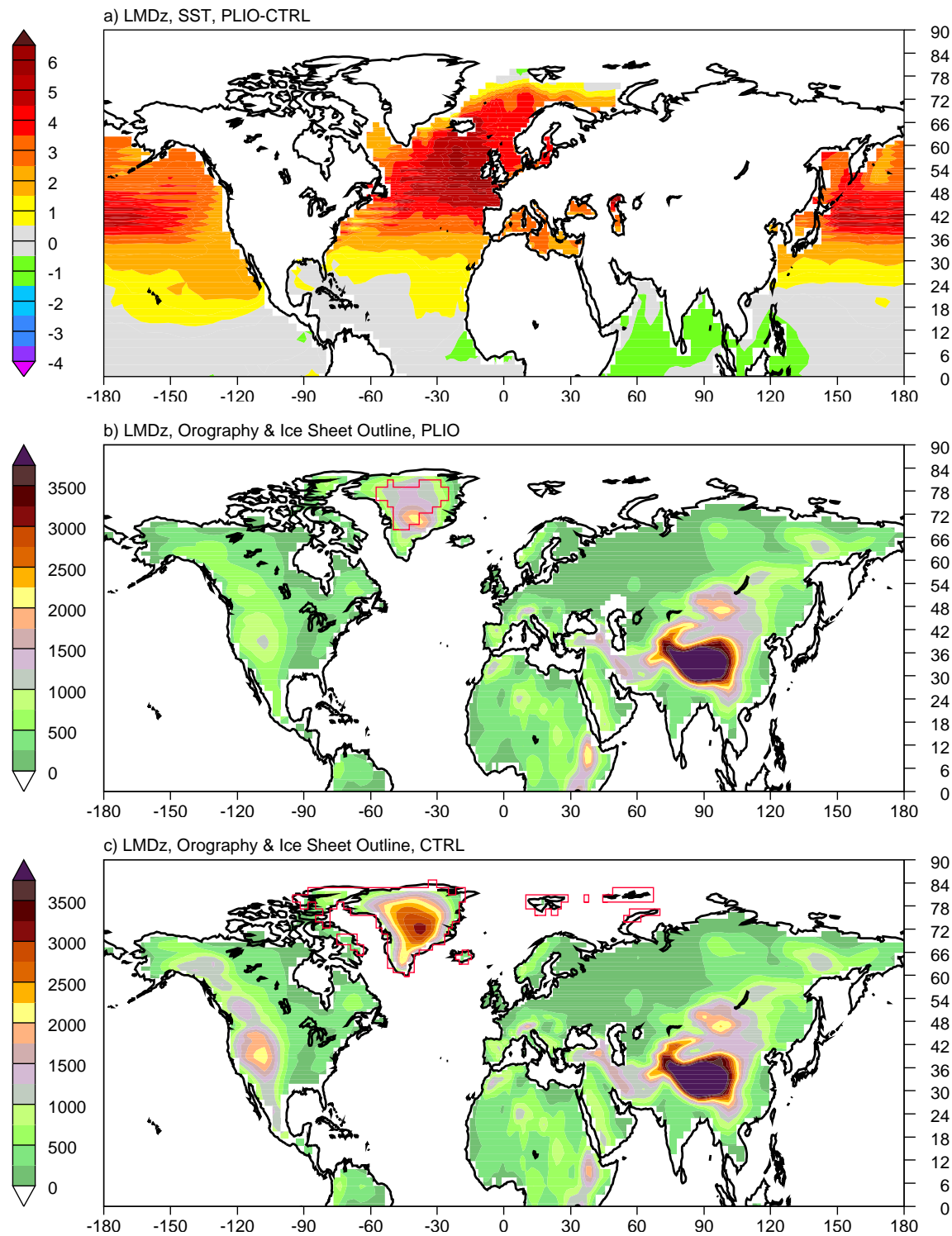

Fig. 1. Mid-Piacenzian paleoenvironmental conditions in the Northern Hemisphere, originating from PRISM2 (Dowsett et al., 1999): (a) mean annual SST anomaly $\left({ }^{\circ} \mathrm{C}\right)$ from the present climate (Taylor et al., 2001); (b) mid-Piacenzian absolute values of orography (m) and ice sheet outline in red, as compared to (c) present.

absence of a realistic and extensive geological reconstruction, in particular in the study area, we computed a high resolution mid-Piacenzian topography by adjusting the $2^{\circ} \times 2^{\circ}$ PRISM2 set of elevations to the finer grid, given the present spatial variability (see Fig. 1). The modern value from the high resolution control run over the finer grid is multiplied by the ratio between the modern value aggregated to the coarser grid and the PRISM2 value. This is done at each fine-grid point after the ratio has been first smoothed at low resolution and then simply refined on the high resolution grid. It results that our experimental design accounts for the influence of a better resolved orography, but not for the specific impact of regional orographic changes from modern.
As far as the vegetation is concerned, we employ ORCHIDEE (Krinner et al., 2005), the land surface component of the IPSL coupled GCM, to simulate the vegetation distribution of the PRISM Interval. ORCHIDEE is a terrestrial biosphere model that calculates the energy and hydrology budgets and simulates the principal processes of the continental biosphere influencing the global carbon cycle as well as changes in vegetation distributions. ORCHIDEE is composed of the Soil-Vegetation-Atmosphere Transfer scheme SECHIBA (Schématisation des Echanges Hydriques à l'Interface Biosphère-Atmosphère) (Ducoudré et al., 1993) and of the carbon module STOMATE (Saclay-ToulouseOrsay Model for the Analysis of Terrestrial Ecosystems), 
which includes the vegetation dynamics part of the LPJ (Lund-Postdam-Jena) model (Sitch et al., 2003). The reader is referred to Krinner et al. (2005) for a more detailed description of the ORCHIDEE model and its validation.

ORCHIDEE is designed either to be coupled to a GCM or forced by climatic data. Here it is run in stand-alone mode, as the fully coupled model was still in development at the time of running the experiments. We therefore opted for an asynchronous coupling of our global vegetation and climate models. We use the same vegetation cover as in the control simulation, i.e. modern (including anthropogenic) vegetation cover in a first experiment, hereafter referred to as PLIOmodernveg. We did not specify PRISM2 vegetation distribution as a starting point because its translation to combinations of ecological functioning categories used by the land surface model may add uncertainty and bias due to a lack of coherence between land cover types and plant functional type (PFT) classification. We then simulate the vegetation for the mid-Piacenzian period by forcing ORCHIDEE with the climate outputs derived from PLIO-modernveg. ORCHIDEE is capable of predicting the geographical vegetation distribution using twelve PFTs and bare soil that can co-exist within one model grid-cell, in response to a set of GCM-derived climatic variables. The forcing data for ORCHIDEE are produced by a weather generator, driven by the monthly anomalies fields between the simulated mid-Piacenzian climate and the results of the CTRL simulation, added to a present-day observed climatology (New et al., 1999). The newly predicted mid-Piacenzian vegetation map is then supplied as an additional boundary condition in a second AGCM run, referred to as PLIO-paleoveg. We have not extended the iterative process further as the simulated climate-vegetation equilibrium is usually reached very soon after the first integration (Claussen, 1994) and to save calculation time, given the high resolution. We therefore assume that the continuation of the iterative process would not alter significantly the predicted vegetation types and distribution. The use of ORCHIDEE provides a detailed view of mid-Piacenzian vegetation cover that then can be compared with the palynologic record, despite there not being full compatibility between PFTs used by the model and the biome typology of pollen data. Comparing the two mid-Piacenzian climate simulations also allows a quantification of the influence of the vegetation on calculated warming and moisture levels. However, a potential weakness of our vegetation simulation is that we have not allowed for changes in stomatal conductance and leaf area index (LAI) that result from a higher atmospheric $\mathrm{CO}_{2}$, consistent with the fact that we have not modified this level in the AGCM simulation either. As shown recently, the hydrological consequences of changes in stomatal conductance and $\mathrm{CO}_{2}$ fertilization are not negligible (Gedney and Valdes, 2000; Piao et al., 2007; Alkama, 2007), given their influence on transpiration.

\section{Climate reconstruction from pollen data}

Terrestrial data, i.e. mainly fossil pollen data but also plant megafossil records, vertebrate paleontological or paleohydrological data, have provided the basis for reconstructing the mid-Piacenzian vegetation. Abundant data exist for Europe and the Mediterranean area and many of them were used within the PRISM2 vegetation reconstruction (Dowsett et al., 1999) or the new global biome reconstruction for the midPiacenzian based on a combined proxy and modelling approach (Salzmann et al., 2008). The paleobotanical data also support several paleoclimatic inferences. Here we compare our climate simulation results with climatic estimates based on pollen data covering the mid-Piacenzian in western $\mathrm{Eu}-$ rope and the Mediterranean region, on a quantitative basis.

The climate was reconstructed from pollen data using the "Climatic Amplitude Method" developed by Fauquette et al. $(1998 \mathrm{a}, \mathrm{b})$ to quantify the climate of periods for which no modern analogue of the pollen spectra exists. In this method, past climate variables are estimated by transposing the climatic requirements of the maximum number of modern taxa to the fossil data. This approach does not rely on the analysis of entire pollen assemblages, but on the relationship between the relative pollen abundance of each individual taxa and climate. Presence/absence limits, as well as abundance thresholds, have been defined for 60 taxa from modern pollen spectra and the literature. This method takes into account not only presence/absence criteria but also pollen percentages to provide more reliable reconstructions. For example, low abundances of some subtropical taxa (e.g. Microtropis fallax) are meaningful and should be taken into account as pollen grains of these plants are generally under-represented because suffering some disadvantages in the transport. Conversely, low abundances of wind-pollinated taxa (e.g. Quercus, Alnus) may reflect long-distance transport of these high pollen producers by air and water. In this case, very low pollen percentages are not significant. The most probable climate for a fossil pollen assemblage is estimated as the climatic interval in which the highest number of taxa can exist. The climatic estimate is presented as an interval and as a "most likely value", which corresponds to a weighted mean according to the size of the climatic intervals of all taxa exceeding their presence/absence and/or abundance thresholds. As the precision of the information obtained from a taxon's climatic interval is inversely related to the breadth of this interval, the weights are greater for taxa with smaller intervals.

High latitude/altitude taxa were excluded from the reconstruction process. The identification and exclusion of high latitude/altitude plants are based on numerous palynological studies (e.g. Suc et al., 1995a,b, 1999) showing that the Pliocene vegetation zonation follows a similar latitudinal and altitudinal zonation to the one observed in present-day southeastern China (Wang, 1961), where most of the taxa that had disappeared from Europe by the late Neogene may be found. Therefore, the obtained estimates correspond to the climate 
at low to middle-low altitude (Fauquette et al., 1998a). Also, Pinus and non-identified Pinaceae (due to the poor preservation of these bisaccate pollen grains) have been excluded from the pollen sum of the fossil spectra (Fauquette et al., 1998a, 1999). The pollen grains of these taxa are often overrepresented in the sediments due to their high production and overabundance in air and water (fluvial and marine) transports (Heusser, 1988; Cambon et al., 1997; Beaudouin et al., 2007).

In this paper, we present reconstructions of five bioclimatic variables estimated from the pollen data: the mean annual temperature $\left(T_{\mathrm{ann}}\right)$, the temperatures of the coldest and of the warmest months $\left(T_{\text {cold }}\right.$ and $\left.T_{\text {warm }}\right)$, the mean annual precipitation $\left(P_{\mathrm{ann}}\right)$ and the moisture index $\alpha$ (i.e. the ratio of the mean annual actual to potential evapotranspiration, $\mathrm{E} / \mathrm{PE})$. The climate in western Europe and in the western Mediterranean area is estimated using pollen spectra from the sites of Susteren 752/72 (Zagwijn, 1960), La Londe K (Clet and Huault, 1987), Saint-Isidore (Zheng, 1990), Garraf 1 (Suc and Cravatte, 1982), Tarragona E2 (Bessais and Cravatte, 1988), Rio Maior F16 (Diniz, 1984a,b), Andalucia G1 (Suc et al., 1995a), Habibas 1 (Suc et al., 1999) and Oued Galaa (Suc, 1989) (Fig. 2f). Some of these climatic estimates have already been published: mean annual temperatures and precipitation values are given in Fauquette et al. (1998a,b, 1999, 2007).

In western Europe, the sites of Susteren, La Londe and Rio Maior show forest vegetation dominated by Taxodiaceae, with Ericaceae and trees of warm mixed forest (Quercus, Carya, Pterocarya, Acer, Carpinus, Fagus). The vegetation rich in Ericaceae is characteristic of the moor landscapes of the Atlantic coast.

In the northern Mediterranean region, sites of Garraf and Saint-Isidore show forest environments dominated by Taxodiaceae (Taxodium/Glyptostrobus or Sequoia depending on local environment conditions, respectively swamps and slopes), accompanied by subtropical evergreen broadleaved plants such as Engelhardia, Symplocos and Distylium. The presence of Cathaya, Tsuga, Cedrus, Abies and Picea in the pollen data indicates the development of mid- to highaltitude conifer forests near the sites.

The site of Tarragona makes the transition from northern to southern Mediterranean region. In the southern Mediterranean region (sites of Tarragona, Andalucia, Habibas and Oued Galaa), herbs are prevalent, trees are scarce, certainly developed on reliefs. This region is characterized by Mediterranean xerophytic ecosystems (matorral composed by Olea, Phillyrea, Pistacia, Ceratonia, evergreen Quercus, Nerium, Cistus) and southward, by open steppe-like vegetation dominated by subdesertic plants such as Lygeum, Neurada, Nitraria, Calligonum, Geraniaceae and Agavaceae.

The climate reconstructed from these pollen data shows higher temperatures than today for most of the sites (squares, diamonds, triangles on Fig. 2). Most likely values are about 2 to $6^{\circ} \mathrm{C}$ higher for mean annual temperatures, 0 to $7^{\circ} \mathrm{C}$ for mean temperatures of the coldest month and 0.5 to $5.5^{\circ} \mathrm{C}$ for mean temperatures of the warmest month (except at Oued Galaa: almost $1^{\circ} \mathrm{C}$ lower than today). Mean annual precipitation are higher than today in northwestern Europe (most likely values from 250 to $550 \mathrm{~mm} / \mathrm{yr}$ higher than today), but drier than or equivalent to modern values in the southwestern Mediterranean area (maximum $150 \mathrm{~mm} / \mathrm{yr}$ higher). The distribution of the available moisture anomalies is characterized by minor changes (5-15\%) both in northwestern Europe and North Africa but by a marked increase in southern Europe (from 30 up to more than 50\%), corresponding to high mid-Piacenzian $\alpha$ values, close to their maximum (Fig. 2).

\section{Simulation results over western Europe and the Mediterranean area and model-data comparison}

\subsection{Two-meter air temperatures}

The examination of the two-meter annual mean air temperature anomaly field (PLIO-modernveg minus CTRL) in the study area, i.e. over a sector extending from $15^{\circ} \mathrm{W}$ to $25^{\circ} \mathrm{E}$ and between 30 and $60^{\circ} \mathrm{N}$ (Fig. 2a), reveals warmer conditions compared with the present climate, in response to the imposed PRISM2 mid-Piacenzian boundary conditions. The model results indicate an annual mean terrestrial temperature rise of 1 to $4^{\circ} \mathrm{C}$ on average in western Europe and over the Mediterranean region, as compared with the control simulation. The differences in temperatures appear to be statistically significant over the study area, as confirmed by the use of a Student's T-test at a $99 \%$ confidence level, thus illustrating the consequences of the forcing delivered by warmer SSTs, a reduced sea-ice cover and the altered orography specified in the boundary conditions. Given the proximity of our study area to the North Atlantic, it reveals the strong influence on the European climate of the dramatically warmer SSTs over the North Atlantic (see Fig. 1a), a main factor determining the mid-Piacenzian climate (Jiang et al., 2005). The model-data comparison shows a broad agreement in the general trend of continental warming, even though simulated anomalies are $1-2^{\circ} \mathrm{C}$ weaker than the most likely values from the paleoclimatic reconstructions (Fig. 3a).

Seasonal temperatures are reproduced with a lower accuracy. The model simulation predicts an homogeneous warming during winter months, as indicated by the $T_{\text {cold }}$ anomalies between mid-Piacenzian and CTRL, thus generally overestimating the temperature increase around the Mediterranean basin (Fig. 2b). The latitudinal gradient depicted by pollen data, with decreasing temperatures anomalies from North to South, is therefore not reproduced (Fig. 3b). Concerning the warmest month (Fig. 2c), the model simulates a more moderate warming for the mid-Piacenzian compared to the coldest month but also with more contrast between western Europe and the Mediterranean area. Some regions such as Sicily or Tunisia even experience some slight cooling, also shown by 

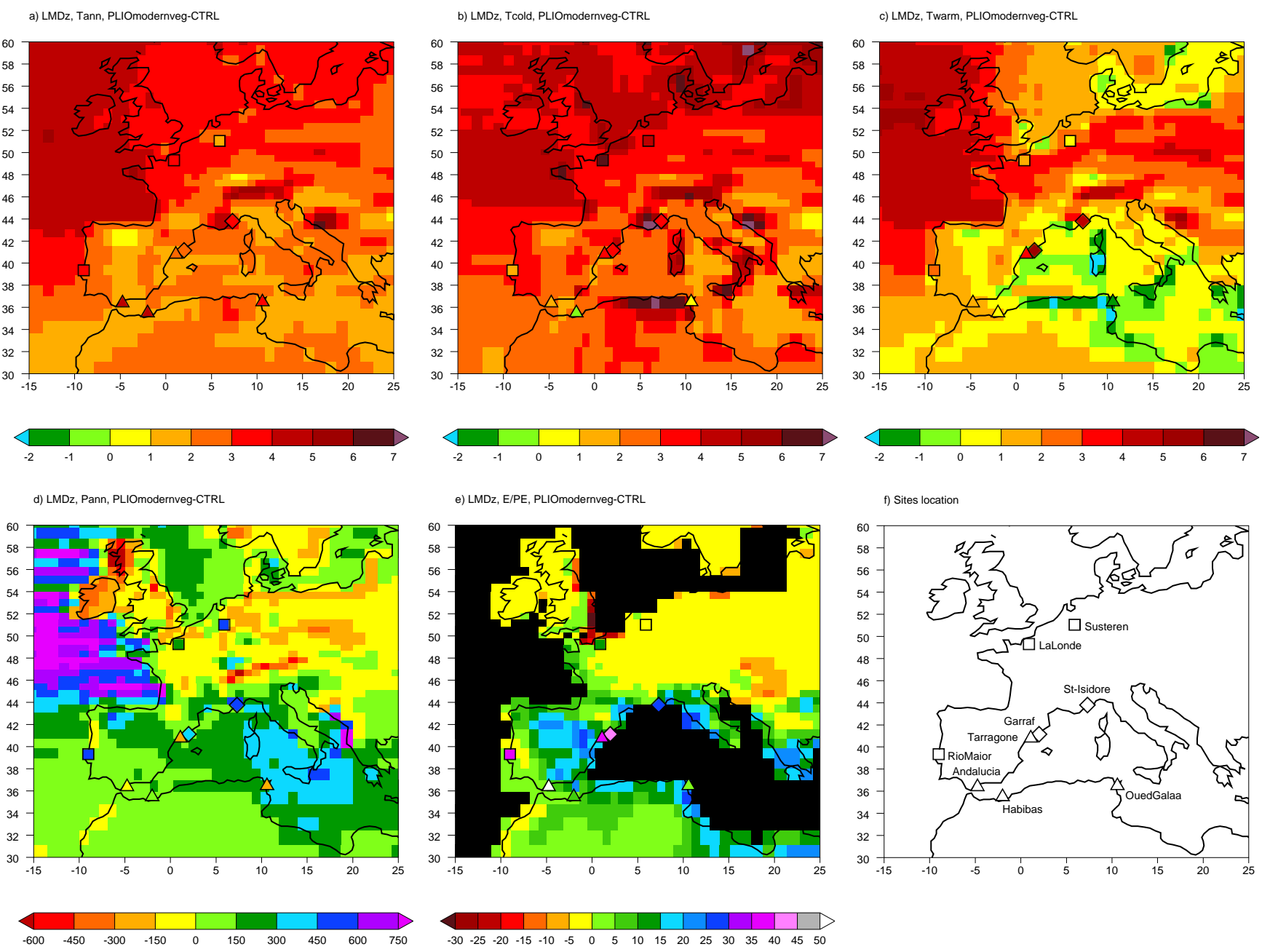

Fig. 2. Mid-Piacenzian anomalies from the present climate, PLIO-modernveg results: (a) annual mean surface temperature $\left({ }^{\circ} \mathrm{C}\right)$, (b) mean temperature of the coldest month $\left({ }^{\circ} \mathrm{C}\right)$, (c) mean temperature of the warmest month $\left({ }^{\circ} \mathrm{C}\right),(\mathbf{d})$ annual mean total precipitation rate $(\mathrm{mm} / \mathrm{yr})$, (e) moisture index (actual/potential evapotranspiration ratio) (\%), as compared with pollen-based climatic reconstructions ( $\mathrm{T}_{\mathrm{ann}}, \mathrm{P}_{\mathrm{ann}}$ from Fauquette et al., 2007). (f) Sites location. Western Europe (squares), northern Mediterranean (diamonds) and southern Mediterranean (triangles) regions are distinguished (see Sect. 3).

the data (Oued Galaa). However, the model does not capture the whole pattern of $T_{\text {warm }}$ reconstructed from pollen data, with greater discrepancies in the northern Mediterranean sector (Fig. 3c).

\subsection{Hydrological cycle}

As compared with the present climate in the study area, wetter conditions dominated during the mid-Piacenzian: the precipitation anomaly computed by the model for the mid-Piacenzian conditions (PLIO-modernveg run) is $\sim 20 \%$ higher over the study area compared with the CTRL experiment. However, this general pattern hides regional heterogeneities in the distribution of mean annual precipitation (Fig. 2d). A general increase in precipitation by up to more than $900 \mathrm{~mm} / \mathrm{yr}$ is simulated over the North Atlantic Ocean. Enhanced precipitation is also observed over the Mediterranean Sea: simulated annual mean precipitation anomalies during the mid-Piacenzian is as high as $\sim 380 \mathrm{~mm} / \mathrm{yr}$, which represents a $67 \%$ increase relative to modern values. Conversely, precipitation slightly decreases, by a few percents, over continental western Europe. A further examination reveals that the precipitation decrease over western Europe is mainly derived from a large reduction of large-scale precipitation. However, increased convective activity occurs over the continent, especially during summer (Fig. 4).

Estimates of mean annual precipitation show far less consistency between model results and data than for temperatures, although biases remain moderate, i.e. lower than $300 \mathrm{~mm} / \mathrm{yr}$ for the whole domain (Fig. 3d). The main 

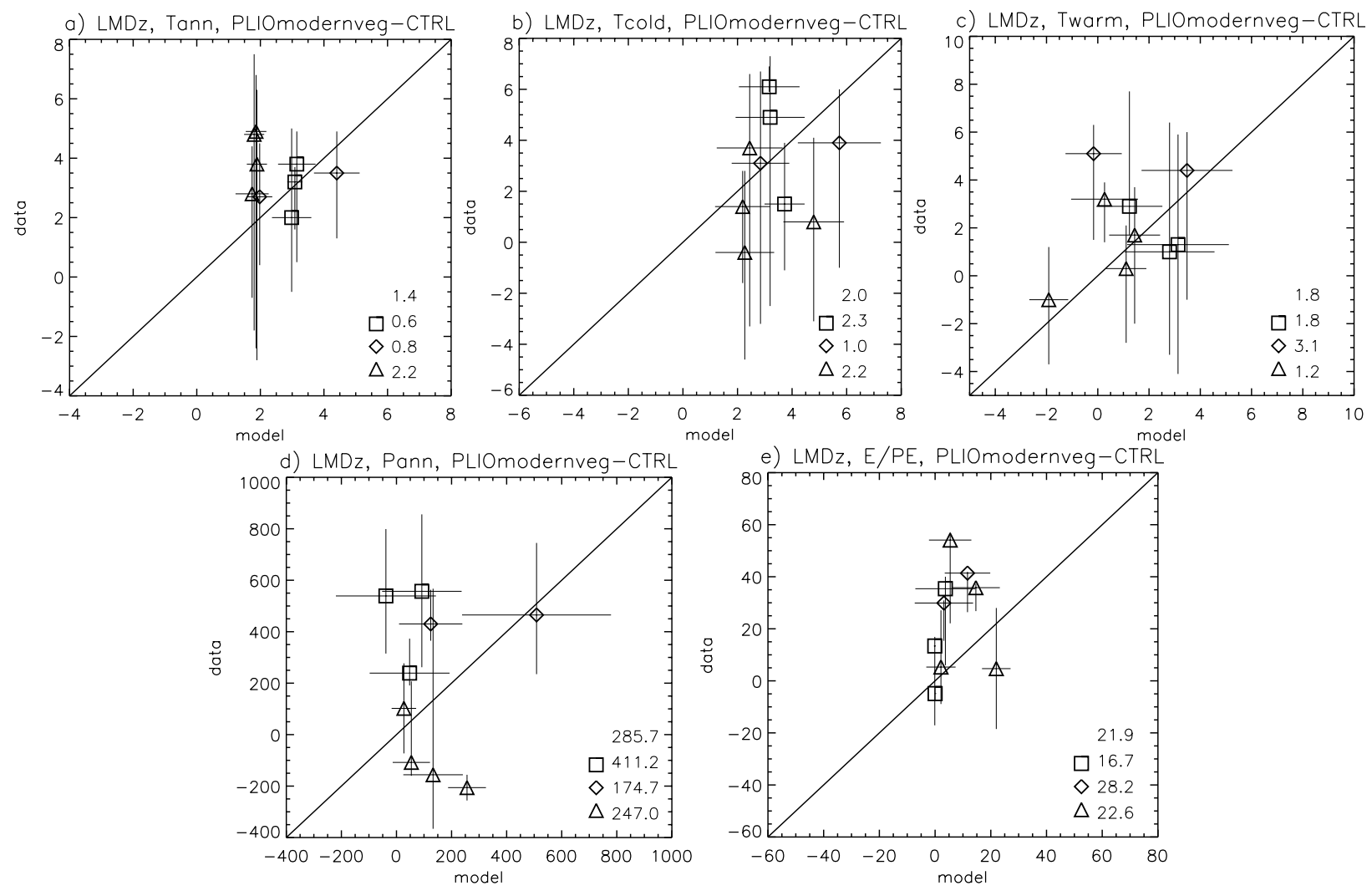

Fig. 3. Mid-Piacenzian anomalies from the present climate, PLIO-modernveg results: (a) annual mean surface temperature $\left({ }^{\circ} \mathrm{C}\right)$, (b) mean temperature of the coldest month $\left({ }^{\circ} \mathrm{C}\right),(\mathbf{c})$ mean temperature of the warmest month $\left({ }^{\circ} \mathrm{C}\right),(\mathbf{d})$ annual mean total precipitation rate $(\mathrm{mm} / \mathrm{yr}),(\mathbf{e})$ moisture index (actual/potential evapotranspiration ratio) (\%). Models results (x-axis) are compared with pollen-based indicators (y-axis). At the bottom right of each plot, numbers indicate mean absolute errors from the best estimates, for the whole domain and for each cited region (western Europe (squares), northern Mediterranean (diamonds) and southern Mediterranean (triangles)). Horizontal bars represent model standard deviations of interannual variability and vertical bars climatic intervals estimated from fossil pollen assemblages.

discrepancy concerns the latitudinal distribution of the precipitation. Indeed, in western Europe and the northern Mediterranean area, model results underestimate the wetter conditions depicted by pollen data (except at Saint-Isidore). Conversely, throughout the southern Mediterranean sector, positive PLIO-CTRL anomalies are indicated by model results, which only correspond to the reconstructions at one out of the four southern Mediterranean sites. The precipitation at the other 3 sites is actually decreasing by up to $200 \mathrm{~mm} / \mathrm{yr}$, which is not at all reproduced by the model.

Model estimates of hydrological variables such as the available moisture show a similar PLIO-CTRL anomalies distribution to that of the mean annual precipitation (Fig. 2e vs. 2d). Terrestrial areas of northern Europe display a midPiacenzian E/PE ratio similar to the modern one in northern Europe, in agreement with the data. The mid-Piacenzian experiment predicts an increase in available moisture all around the Mediterranean basin that however does not reach the high levels indicated by pollen data along the Spanish coast (Figs. 2e and 3e).

\subsection{Mid-Piacenzian vegetation distribution and vegetation-induced effects on climate}

\subsubsection{Mid-Piazencian vegetation as simulated by ORCHIDEE}

The DGVM ORCHIDEE provides insights into the distribution and character of the mid-Piacenzian vegetation cover as a consequence of warmer climate. During the midPiacenzian, Europe is dominated by temperate broad-leaved (western Europe and Mediterranean) or needle-leaved (eastern Europe) evergreen forest, in general combined with a lesser fractional coverage of grassland. Some tropical plant functional types are predicted along the southern Atlantic and Mediterranean coasts, which are absent from this region today. In response to a cooler modern climate, this vegetation cover has been mainly replaced by temperate broadleaved deciduous forest in Europe and predominant herbaceous plants in the south, associated with an increased of bare soil in North Africa, as suggested for instance by the 
a) LMDz, Plarge-scale, PLIOmodernveg-CTRL
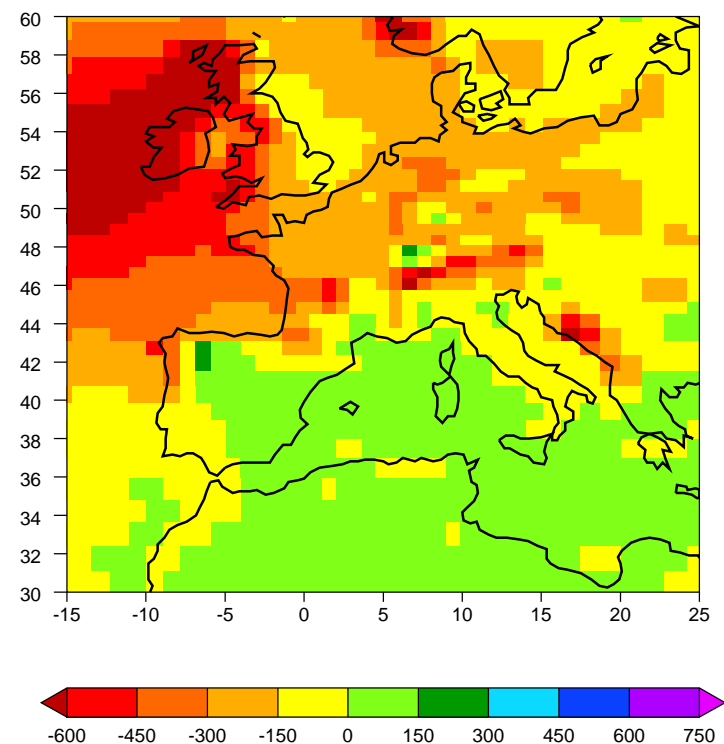

b) LMDz, Pconvective, PLIOmodernveg-CTRL

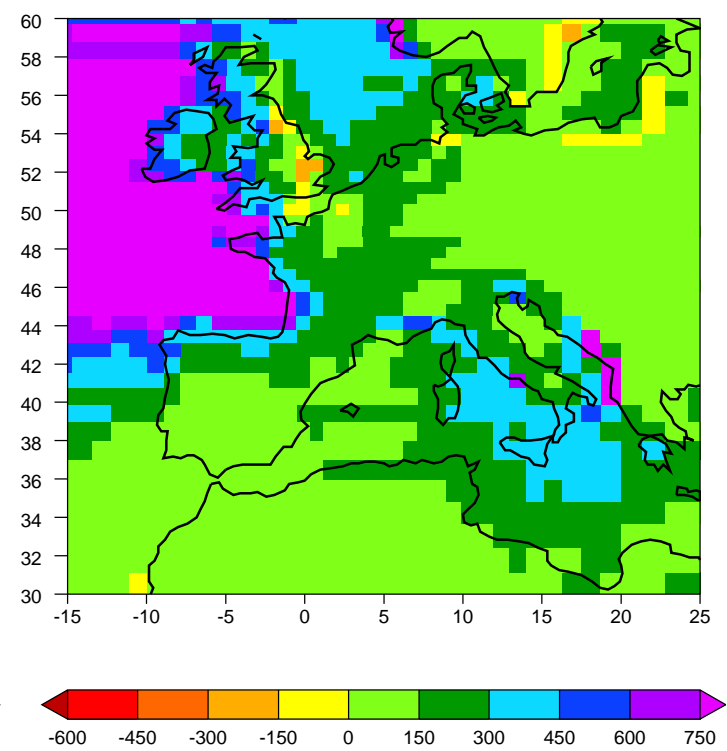

Fig. 4. (a) Large-scale precipitation and (b) convective precipitation, in mm/yr. Mid-Piacenzian anomalies from the present climate, PLIOmodernveg results.

estimate of Potential Natural Vegetation (PNV) adapted to PFTs from the Sterling and Ducharne (2008) comprehensive data set.

The lack of coherence between the combination of PFTs used by land surface models and land cover classes provided in maps or biomes from pollen data usually hampers the comparison of vegetation distributions. The major vegetation changes simulated by ORCHIDEE are nonetheless broadly consistent with other reconstructions of mid-Piacenzian vegetation (Dowsett et al., 1999; Favre, 2007; Salzmann et al., 2008). Pollen data and vegetation simulations are generally in good agreement, especially concerning the expansion of a warm-temperate forest in Europe, despite few discrepancies. For instance, pollen data show for southern Spain and North Africa an open subdesertic landscape dominated by grasses, indicating arid conditions. However, arboreal pollen grains are also present, indicating that trees were certainly developing on reliefs. Another noticeable difference is the presence of tropical PFTs simulated by ORCHIDEE, whereas only subtropical plants are recorded in pollen data. There is actually no subtropical PFT categorie in the PFT scheme from ORCHIDEE, only tropical, temperate or boreal fractional coverage. To the East, the fractional coverage of 10 to $30 \%$ of boreal broad-leaved trees predicted by ORCHIDEE may be overestimated compared to pollen data, which only show the presence of boreal needle-leaved species in eastern Europe, most probably at altitude.

As compared to the modern anthropogenic vegetation distribution used in the PLIO-modernveg simulation (Fig. 5), the ORCHIDEE results for the PRISM Time Slab are even more different. The main vegetation differences that may have an impact on the simulated climatology in the PLIO-paleoveg experiment include a general expansion of temperate forest cover in Europe and the Mediterranean region for the midPiacenzian (predicted fractional coverage of more than $90 \%$ over $20 \%$ of the land, up to $45 \%$ for all tree types), whereas the major part of the present vegetal cover consists of crops, and a reduced coverage of arid desert in North Africa (by $20 \%)$.

\subsubsection{Vegetation-induced effects on climate}

As far as the vegetation impact on climate is concerned, the main differences in experiment PLIO-paleoveg compared with the PLIO-modernveg run are shown on Fig. 6. The spatial average of the mean annual temperature difference over the region of interest is on the order of a tenth of a degree between the two simulations over continental Europe. The PLIO-paleoveg-CTRL $\mathrm{T}_{\mathrm{ann}}$ anomalies are thus very similar to the previous PLIO-modernveg-CTRL one. The addition of the paleovegetation produces few statistically significant changes in the modelled climate, except over some areas such as North Africa where an annual mean cooling that reaches more than $1^{\circ} \mathrm{C}$ is simulated and in a few other cases, such as over northwestern Europe (British Isles) and the Alps that are slightly, up to around $0.5^{\circ} \mathrm{C}$, warmer (not shown). The model's sensitivity to Late Pliocene land cover characterization is therefore limited in terms of 2-m mean annual temperature changes over the studied area. 

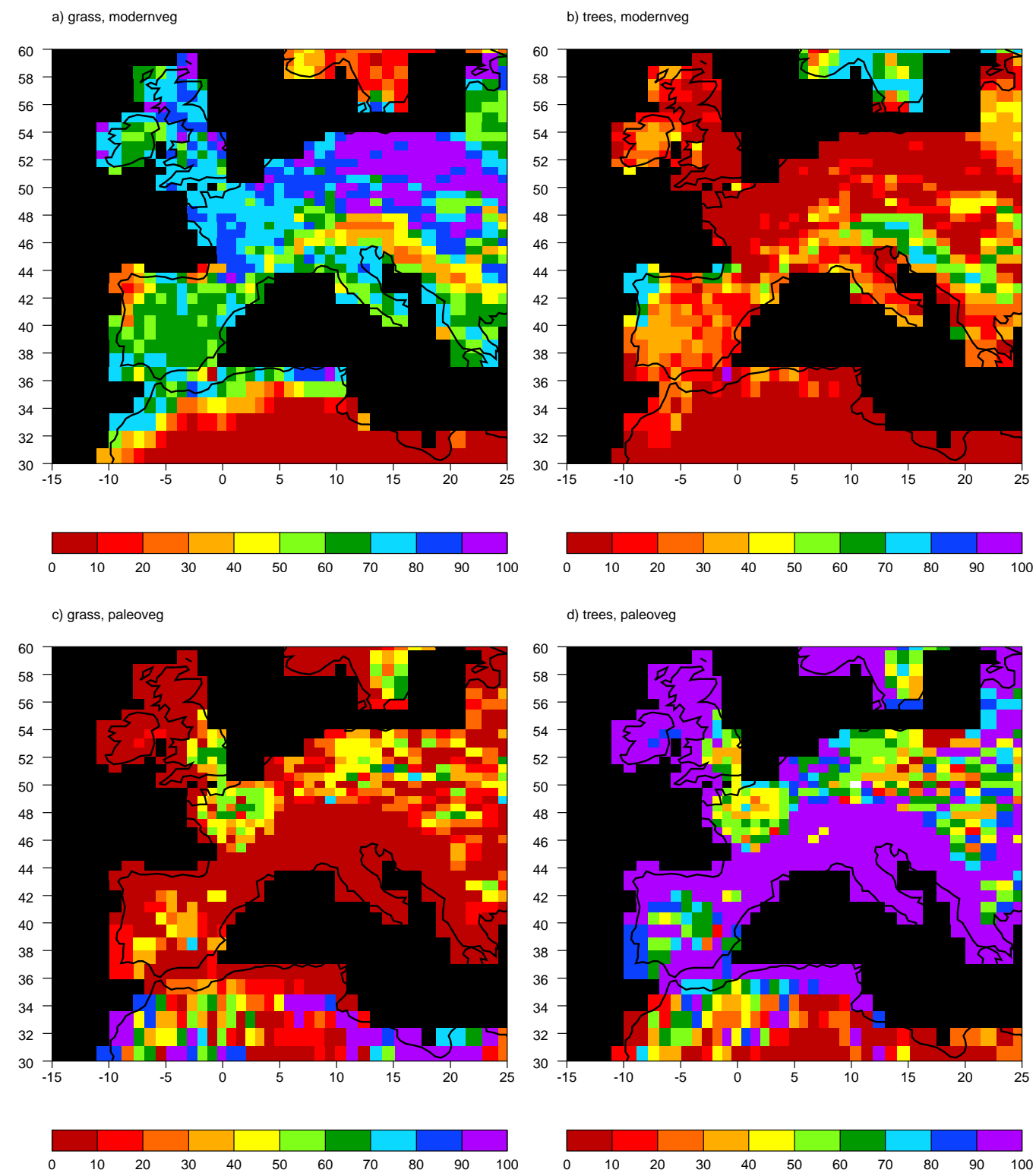

d) trees, paleoveg

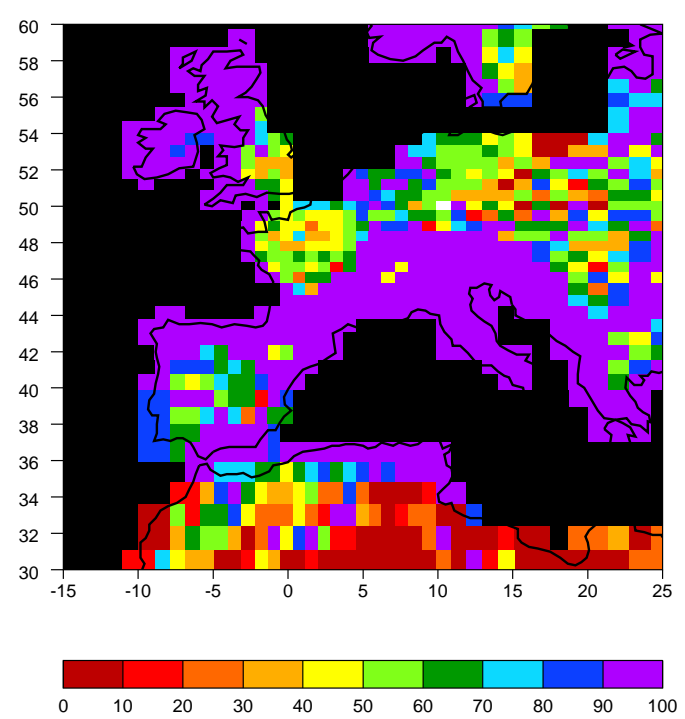

Fig. 5. Maximum percentage of herbaceous and arboreal coverage, i.e. the fraction calculated as the combination of grasses and crops and the sum of the arboreal PFTs, respectively, in the modern vegetation and simulated by ORCHIDEE for the mid-Piacenzian epoch: (a) modern herbaceous fraction, (b) modern arboreal fraction, (c) mid-Piacenzian herbaceous fraction, (d) mid-Piacenzian arboreal fraction.

The vegetation impact on the simulated climate mainly occurs during the summer season (Fig. 6). Simulated temperatures of the warmest month (Fig. 6a) are reduced by $0.9^{\circ} \mathrm{C}$ on average on the studied area, cooler by 1 to $2^{\circ} \mathrm{C}$ over western Europe and North Africa, and as much as $3^{\circ} \mathrm{C}$ over eastern Europe, as compared with PLIO-modernveg. The most significant variations are observed over the latter regions. They correspond to a reduced summer warming over Europe and cooler $T_{\text {warm }}$ over North Africa at mid-Piacenzian times, relative to the present. In winter, the vegetation-induced cooling is not significative.
As regards the model-data comparison, the effect of the more realistic vegetation treatment is quite negligible and does not induce any improvement of the simulated mean annual cycle of 2-m air temperature (Fig. 7). The lack of observations located further inland in areas displaying statistically significant differences prevents from evaluating the accuracy of the summer temperature anomalies trend provided by the PLIO-paleoveg experiment.

Examining model diagnostics for the annual precipitation (not shown) indicates average conditions that are rather drier than the PLIO-modernveg pattern, with negative local disparities, from 50 to $-250 \mathrm{~mm} / \mathrm{yr}$, between the two 
a) LMDz, Twarm, PLIOpaleoveg-PLIOmodernveg
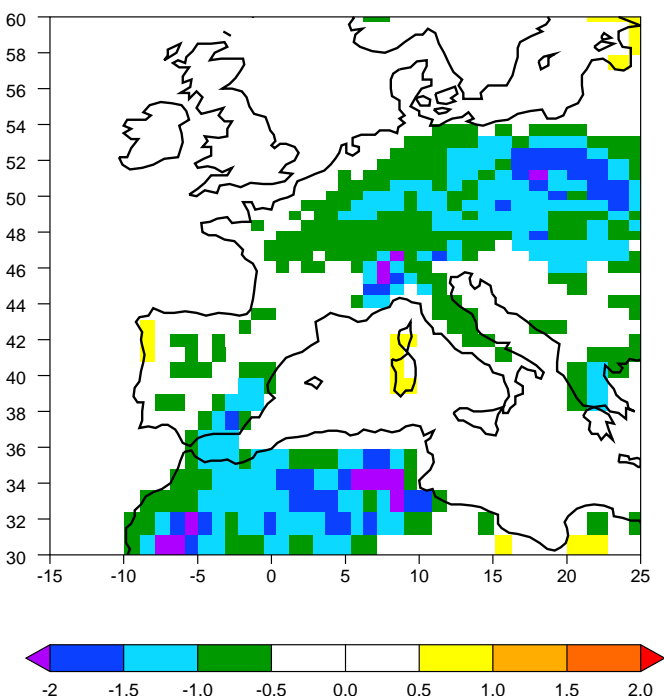

c) LMDz, Albedo, PLIOpaleoveg-PLIOmodernveg
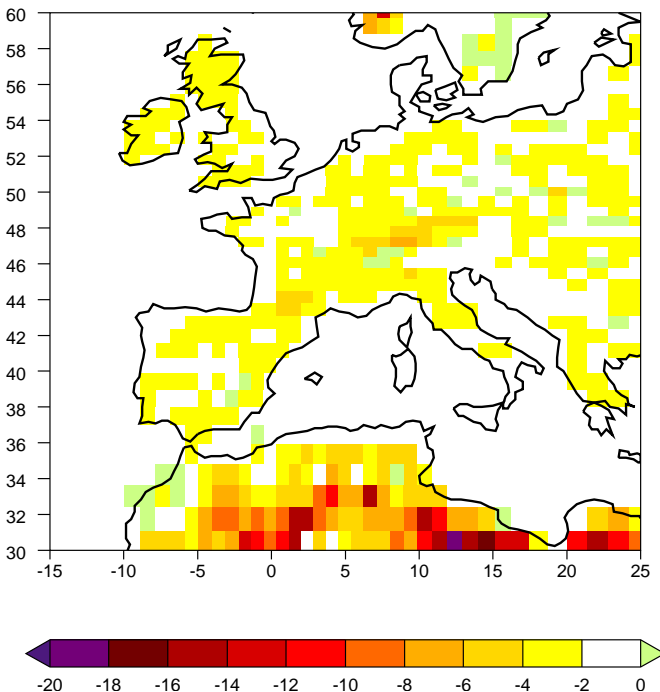

b) LMDz, P, JJA, PLIOpaleoveg-PLIOmodernveg
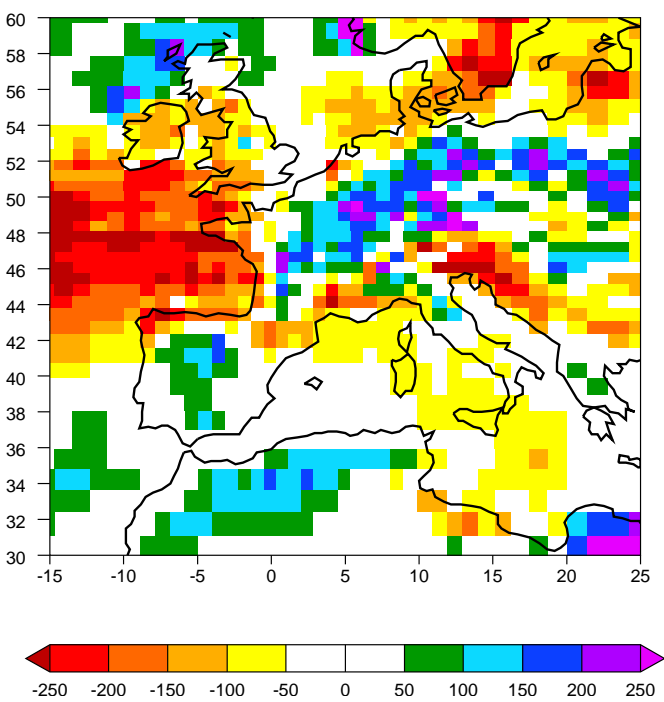

d) LMDz, ET, JJA, PLIOpaleoveg-PLIOmodernveg

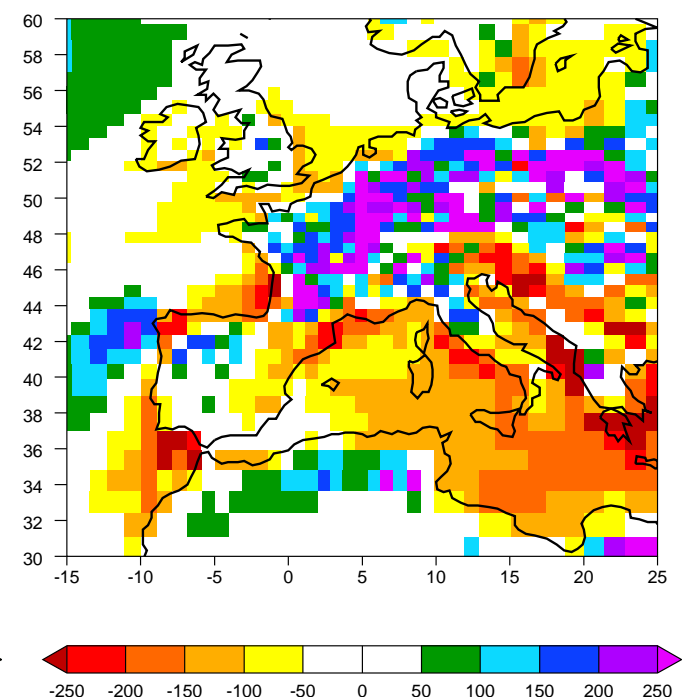

Fig. 6. Anomalies between PLIO-paleoveg and PLIO-modernveg runs: (a) mean temperature of the warmest month $\left({ }^{\circ} \mathrm{C}\right)$, (b) summer $(\mathrm{JJA}$ : June, July and August) total precipitation rate (mm/yr), (c) albedo (\%), (d) summer (JJA: June, July and August) evapotranspiration (mm/yr).

runs. Variations in the intensity of precipitation are centred around the Alps but are rarely statistically significant, except over parts of northwestern Europe. PLIO-paleoveg-CTRL negative anomalies are more pronounced over northwestern Europe than PLIO-modernveg-CTRL whereas the Mediterranean basin records smaller positive anomalies. As a result, the model-data comparison for this variable is even less satisfactory over western Europe and the northern Mediterranean when a more realistic vegetation is introduced in our Late Pliocene experiment but slightly improves over the southern Mediterranean region (Figs. 3 and 7). The decrease in precipitation rate can be explained by a further decrease in largescale precipitation, throughout the year, except in summer, during which the increase in convective precipitation contributes to a wetter season in the PLIO-paleoveg experiment, as compared to PLIO-modernveg (Fig. 6b).

E/PE values computed for PLIO-paleoveg results are similar to those of PLIO-modernveg over northwestern Europe. Significant changes in the ratio between the two experiments are recorded over the same areas as those regarding annual precipitation, i.e. north and west of the Mediterranean Sea. They result in a marked decrease, by down to $-25 \%$, in the available moisture in the PLIO-paleoveg experiment, compared to PLIO-modernveg. PLIO-paleoveg-CTRL anomalies are still positive in most of the Mediterranean area but lower than their PLIO-modernveg-CTRL counterparts 

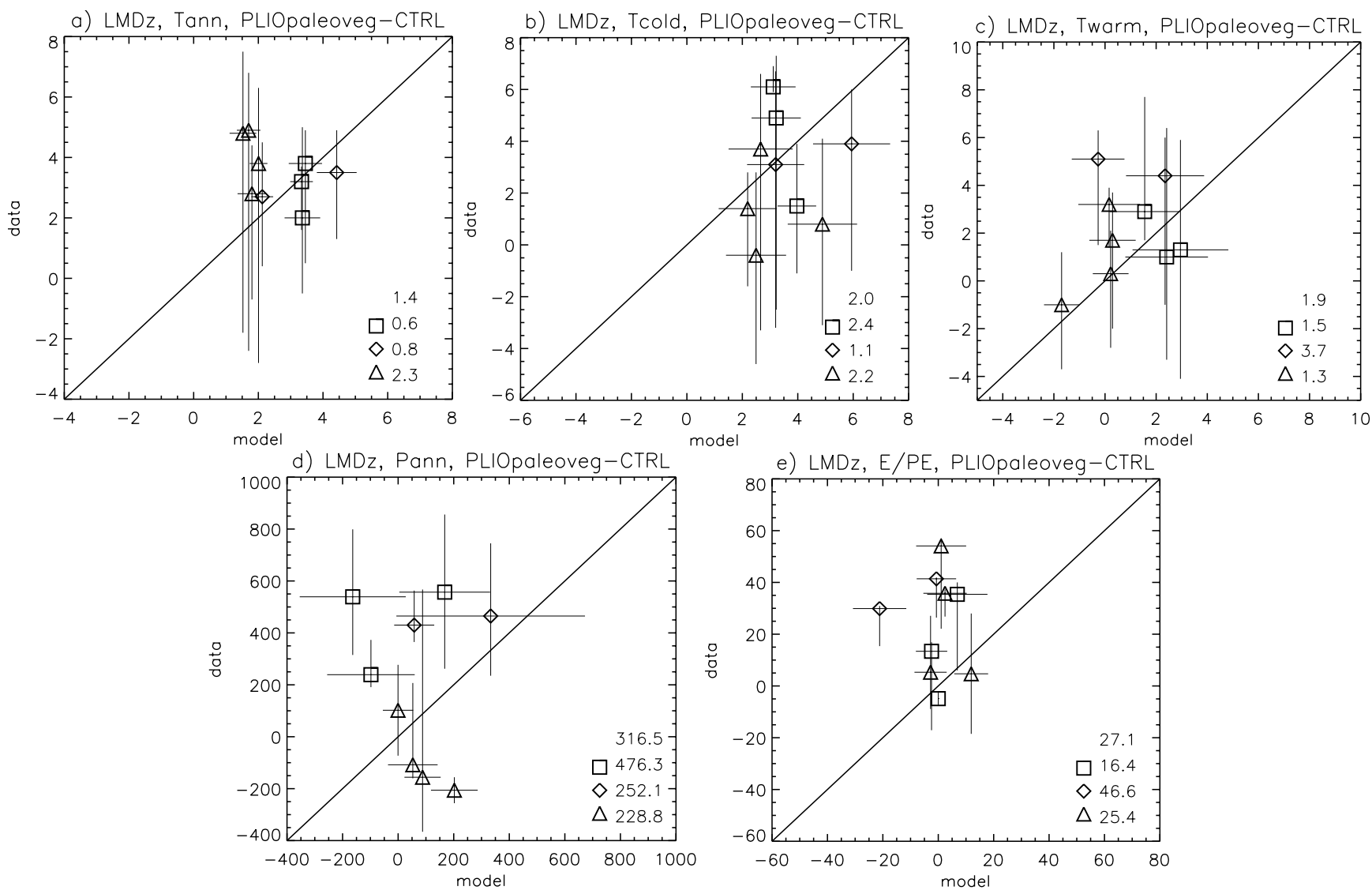

Fig. 7. Same as for Fig. 3 but PLIO-paleoveg results.

and exhibit negative values over southeastern Europe. The model-data comparison therefore slightly deteriorates (Fig. 7).

\section{Discussion}

In this study, we have first investigated the ability of the high resolution zoomed version of the LMDz AGCM to reproduce the warmer and slightly wetter conditions of the midPiacenzian by means of a quantitative model - pollen data comparison over Europe and the Mediterranean area. Then we have considered the relative impact of the reconstructed vegetation on the simulated climatic response at the regional scale.

\subsection{High resolution climate modelling in a warmer context}

\subsubsection{A good agreement for near surface temperatures}

For the mean annual near surface temperature field, the simulated mid-Piacenzian warming relative to the present is broadly consistent with previous modelling studies, partic- ularly that of Haywood et al. (2000b) for the study area, and with the quantitative paleoclimatic reconstructions (Fauquette et al., 2007). For most sites, the discrepancy is small given both the interannual variability of the model and the large and less precise entire climatic intervals surrounding the most likely values reconstructed by the pollen indicators (Fig. 3a).

Some biases remain, i.e. underestimated $T_{\mathrm{ann}}$, which is not unexpected since our experimental design does not encompass all of the forcings that are possible for this epoch, particularly the changing $\mathrm{CO}_{2}$ levels. But the consequence of a $\sim 85$ ppmv lower value of the atmospheric $\mathrm{CO}_{2}$ concentration should be modest because the dominant part of their effect is already incorporated in the prescribed SSTs. The direct physiological impact of higher than today $\mathrm{CO}_{2}$ concentrations on vegetation is not accounted for either in the paleoclimate reconstructions themselves, which may lead to significant bias (Wu et al., 2007). For the colder period of the Last Glacial Maximum, a better agreement between simulated and reconstructed winter cooling over western Europe and the Mediterranean area has been mainly achieved by explicitly accounting for the $\mathrm{CO}_{2}$ decrease in the new climate reconstructions (Ramstein et al., 2007). 
Inconsistencies between simulated and reconstructed seasonal temperatures could reflect the inadequation between SSTs over the Mediterranean Sea and pollen data that are located along the coast. The increase in summer SSTs between mid-Piacenzian and CTRL is too low as compared to the $T_{\text {warm }}$ anomalies depicted by pollen data over the northern Mediterranean but too high in winter as compared to the $T_{\text {cold }}$ anomalies according to pollen data over the southern Mediterranean. As model results are influenced to a large extent by the SST forcing (see Kageyama et al. (2005) for a similar result in a glacial context), it would be worth testing the range of this forcing within the PRISM time-slab. Over the Mediterranean Sea, maximum and minimum warming SST reconstructions indicate a possible $\sim 1^{\circ} \mathrm{C}$ change (Dowsett et al., 2005). A representation of the SST pattern consistent with ocean-atmospheric fluxes could also be simulated by a high resolution model of the Mediterranean Sea locally coupled with a global atmosphere model, such as the Sea Atmosphere Mediterranean Model (SAMM) (Somot et al., 2008). Moreover, the introduction of an active Mediterranean Sea significantly amplifies the 21st climate change response over large parts of Europe, with respect to its corresponding Atmosphere Regional Climate Model. Indeed, climate change projections based on many global and regional models agree about a pronounced warming of several degrees for the end of the 21st century over the Mediterranean region, with a maximum in the summer season (Giorgi and Lionello, 2008). This region might be especially vulnerable to future global climate change. The greater warmth experienced during the mid-Piacenzian period is comparable to what is projected over the Mediterranean area, although seasonal temperature patterns may differ. It would therefore be worth examining the influence of an interactive Mediterranean Sea or a fully coupled ocean in the mid-Piacenzian context.

\subsubsection{A clear discrepancy for hydrological values}

As regards estimates of precipitation values, the main discrepancy seems to be the underestimation of continental precipitation in much of northern Europe, whereas the precipitation rate is overestimated over the southern Mediterranean, despite a robust pollen data signal. The presence of an extensive wet zone in northwestern and central Europe is moreover suggested by other proxies (small mammals for instance, van Dam, 2006). In this respect, the latitudinal gradient of precipitation indicated by pollen data resembles the general trend that emerges from a review of climate change projections for the 21st century (Meehl et al., 2007). Global warming is expected to cause a large decline of precipitation over the Mediterranean region, except for the northern areas in winter (Giorgi and Lionello, 2008), following what has already been observed during the 20th century (Lionello et al., 2006).

These data-model inconsistencies show a general difficulty to simulate regional hydrologic processes, even when using a refined-grid numerical model. Salzmann et al. (2008) also identified many discrepancies when comparing precipitation estimates from the HadAM3 GCM and literature for selected regions including the Mediterranean area. The use of a finer resolution model, with a better description of both the orography and small scale dynamics, does not help to provide a simulated precipitation field in better agreement with the data, as it did for the LGM at the European scale (Jost et al., 2005). Thus, the fact that the orography of the mid-Piacenzian is not described properly (e.g. the weaker constraints on the elevation of the Alps and the Pyrenees) may be part of the explanation of this different behaviour. In this respect, the sensitivity to the Alps and Pyrenees elevation would be worth studying.

One of the factors which could explain the continental precipitation underestimation over western Europe is the simulated decrease of large-scale precipitation. In the model, large-scale precipitation is defined as the part of the precipitation related to moisture convergence due to large-scale atmospheric circulation, as opposed to convective precipitation, which is related to instable atmospheric vertical profiles. Large-scale mid-latitude precipitation is therefore largely related to the development of synoptic scale perturbations over the oceans, especially in winter. Total precipitation notably increases over the warm ocean regions of the North Atlantic, rising by more than $30 \%$ as compared with the present-day control case as an annual mean. This increase is attributable to preponderant moist convective precipitation events, which outweigh a diminished large-scale precipitation pattern. Indeed, the former represents $60 \%$ of the total precipitation signal in the PLIO experiment for only $20 \%$ in the CTRL one. High levels of evaporation are also simulated for the North Atlantic and are responsible for a large increase in latent heat fluxes.

These major changes in evaporation and convective precipitation are positively correlated with the prescribed SSTs, one of the main factors determining the mid-Piacenzian climate together with a reduced sea ice extent (Jiang et al., 2005). The pattern of greatest warming with increasing latitude was recently confirmed by the re-evaluation of midPiacenzian North Atlantic SST estimates by means of a multiproxy analysis (Robinson et al., 2008). The North Atlantic is nonetheless the region that encompasses the greastest temporal variability within the mid-Piacenzian warm period (Dowsett et al., 2005), of the order of $\pm 2-3^{\circ} \mathrm{C}$. Additional experiments including these new SST reconstructions are necessary to investigate in detail the impact of the SST distribution over the North Atlantic on the European continental climate. The sensitivity of the European climate to North Atlantic SSTs has already been pointed out for a glacial context by Pinot et al. (1999) from AGCM experiments and by Kageyama et al. (2006) for coupled ocean-atmosphere experiments. In a mid-Piacenzian ocean-atmosphere coupled experiment (Haywood and Valdes, 2004; Haywood et al., 2007), total precipitation rates are reduced over the North 

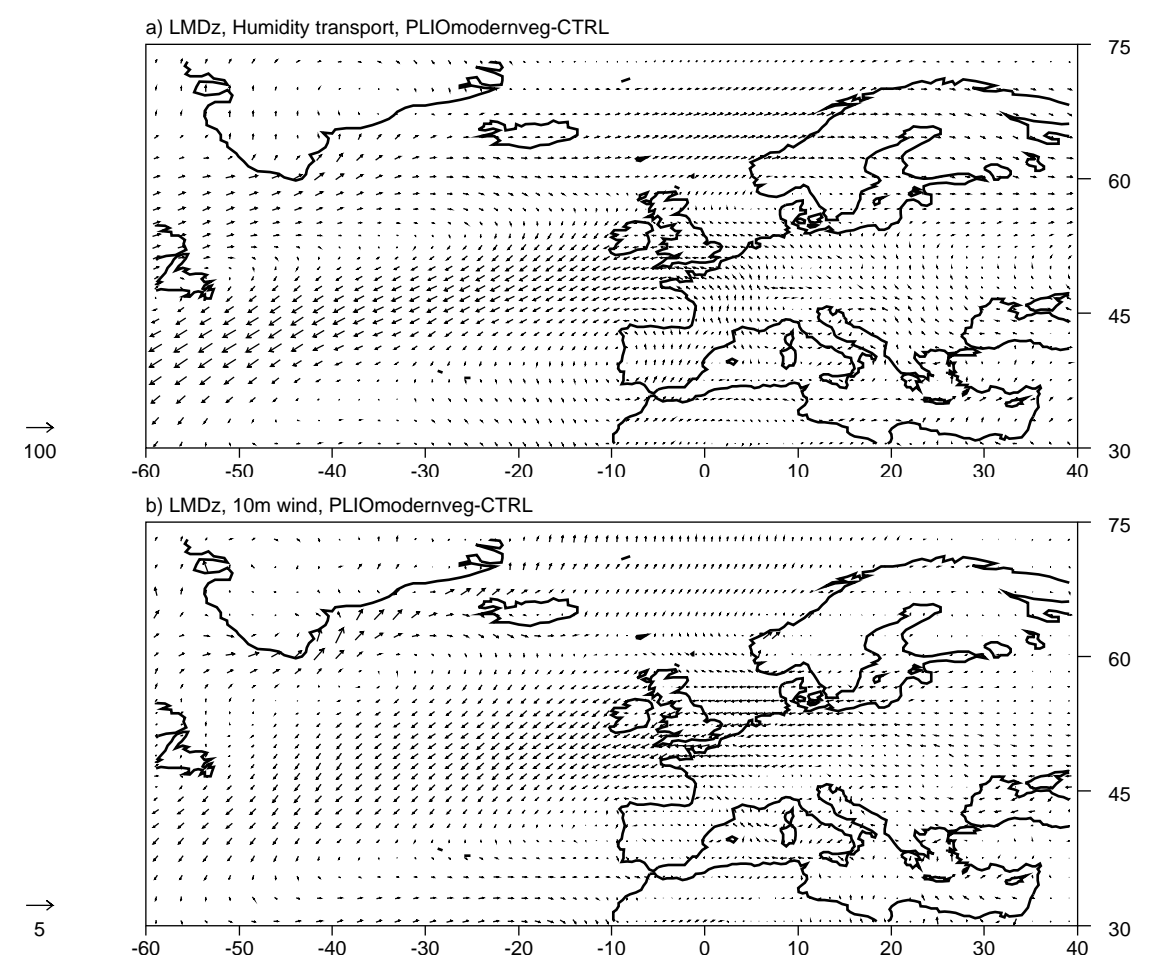

Fig. 8. (a) Humidity transport and (b) surface wind vectors $(\mathrm{m} / \mathrm{s})$ over North Atlantic. Mean annual mid-Piacenzian anomalies from the present climate, PLIO-modernveg results.

Atlantic compared to the fixed SST experiment, particularly in winter, because of lower SSTs predicted by the model over this region. Indeed, the inclusion of an interactive ocean would allow a further examination of the potential feedback from the oceans, as it is supposed to have a significant influence on atmospheric dynamics, on ocean-atmosphere fluxes and hence on total precipitation rates. In particular, it would allow a better representation of the possible enhanced meridional ocean heat transport, which could compensate the simulated decrease in intensity of the large-scale atmospheric circulation due to the smaller meridional temperature gradient of the mid-Piacenzian.

The resultant reduced ability of the atmosphere to carry moisture evaporated from the ocean over the continent (Fig. 8a), especially during summer, can therefore account for the fact that the aforesaid additional oceanic humidity supply is not converted into precipitation over the northwestern European continent. A slight weakening of zonal wind speeds, by $1-2 \mathrm{~m} / \mathrm{s}$ over North Atlantic and up to a maximum of $3 \mathrm{~m} / \mathrm{s}$, is also simulated over the northwestern European continent (Fig. 8b). This westerly wind pattern is nevertheless not supported by the data either, as suggested by the development of Ericaceae moors along the European Atlantic coast (Suc et al., 1995a,b) which would rather point to an intensification of the wind strength.
According to basic baroclinic theory (Eady, 1949), the weaker meridional temperature gradient in the North Atlantic should have the effect of decreasing the storminess. However, this is not the case in our PLIO simulations (Fig. 9). Other factors are therefore playing an important role in midlatitude transient eddies. These could develop thanks to more available latent heat flux over the warmer oceans (Hoskins and Valdes, 1990; Laîné et al., 2009). Also, the lower Rockies could modify the connection between the Pacific and Atlantic storm-tracks, favouring more feeding of Atlantic storms by Pacific perturbation remnants (Lunt et al., 2008). The role of these different factors could only be evaluated through dedicated sensitivity experiments (e.g. changing the topography only or the SSTs only compared to the preindustrial conditions). The simulated PLIO large-scale precipitation decrease is all the more surprising since stronger storm-track activity should favour this type of precipitation. It could be, however, that in a case of a warmer ocean such as in PLIO, the increase in storm-track activity favours convective precipitation, to the detriment of large-scale precipitation. This calls for a more detailed study and additional sensitivity experiments which are out of the scope of the present paper.

These results are in contrast with those of other GCMs, which predict weaker storm tracks (Chandler et al., 1994; Sloan et al., 1996). As for the simulated precipitation field, the UKMO AGCM has been able to capture the general 


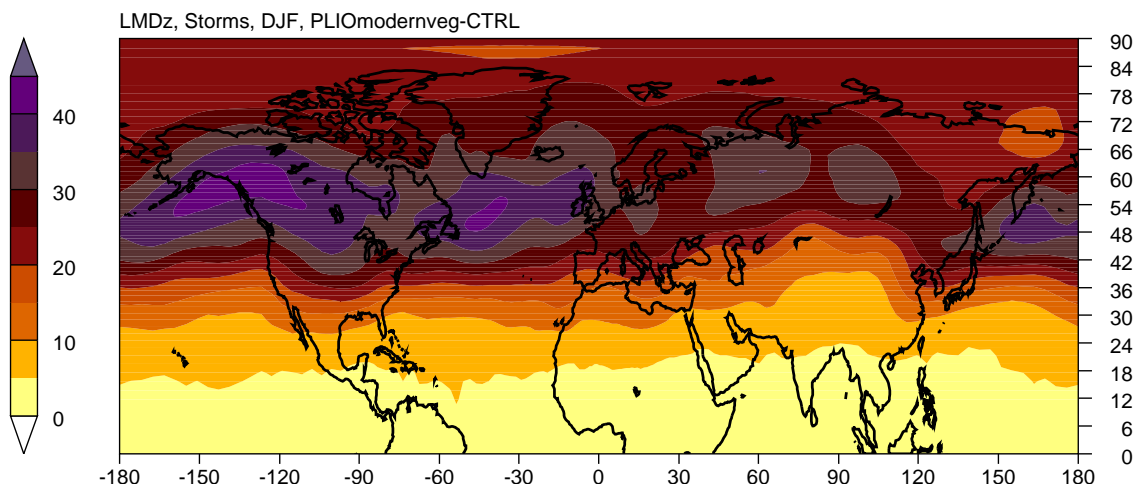

Fig. 9. Storminess $(\mathrm{m})$ in the Northern Hemisphere, defined as the high pressure filtered standard deviation of the $500 \mathrm{hPa}$ geopotential height (the filter keeps the variability for timescales between 2-7 days). Winter (DJF: December, January and February) mid-Piacenzian (PLIO-modernveg results) anomalies from the present climate.

pattern depicted by the data over the study area. Indeed, Haywood et al. (2000b)'s simulations show an annual zonal average precipitation similar to modern values between around 30 and $42^{\circ} \mathrm{N}$ and higher than today between 42 and $51^{\circ} \mathrm{N}$, in particular in western Europe and western Mediterranean, as a result of an enhancement of the westerly atmospheric transport of heat and moisture. Predicted mid-Piacenzian precipitation rates even decrease over the Mediterranean basin as compared with today in their coupled ocean-atmosphere experiment (Haywood and Valdes, 2004; Haywood et al., 2007), in response to a northward shift of the Atlantic storm track and the presence of an enhanced Azores high-pressure system, which helps to divert the Atlantic precipitation from the Mediterranean onto northwestern Europe. Similar features of increased anticyclonic circulation associated with a shift in the location of mid-latitude storm tracks could also lead to the substantial drying of the Mediterranean region that is projected for the near future (Giorgi and Lionello, 2008). On the contrary, a slight increase in precipitation over the Meditarreanean region is simulated by our model in the PLIO experiment (Fig. 4b), which can be partly related to a weakening of the Azores high-pressure system as well as to warmer Mediterranean SSTs.

It is nonetheless difficult to directly compare the climatic response of all of the different models that have already been used to simulate the mid-Piacenzian, since no uniform experimental design was set at the time of performing our experiments. Even the reference climate simulations use a set of boundary conditions from different data bases. The intercomparison between climate models simulations of the midPiacenzian that will be carried out in the near future according to the same set of boundary conditions (Chandler et al., 2008; Haywood et al., 2009) will help to distinguish the effects of the imposed PRISM data sets on the apparent disagreement in the climatic response of the models from the impacts of any internal model physics or missing mechanisms.
As for convective precipitation, a coherent signal is observed between simulated precipitation and temperature over the continent, with increased convective precipitation as compared to present, in particular during the summer season. However, the use of a finer grid numerical model in our experiment, by accentuating the land-ocean contrast, can lead to a higher atmospheric water-holding capacity over land than over the ocean, and thus, a reduced relative humidity for continental air masses advected from the ocean. It can have the effect of tempering the increase in convective precipitation.

In addition, the moisture levels indicated by the data are generally underestimated by the model, meaning that predicted recycling of continental water may not be intense enough. This is of importance since annual variation of land precipitation also partly results from local moisture recycling, despite a greater atmospheric control in the study area. On this point, several issues can be raised.

The relatively low atmospheric $\mathrm{CO}_{2}$ concentration we used in our simulations, as compared with the level commonly used in more recent simulations, hampers the modeldata comparison. On the one hand, the radiative effect of an increase in atmospheric $\mathrm{CO}_{2}$ could produce an intensified hydrological cycle, with increasing soil moisture in the mid-latitudes (Levis et al., 2000). On the other hand, atmospheric $\mathrm{CO}_{2}$ also affects the global hydrological cycle through its direct physiological effect on stomatal conductance and $\mathrm{CO}_{2}$ fertilization, which can either have an amplifying or a dampening impact (Piao et al., 2007; Alkama, 2007). Higher $\mathrm{CO}_{2}$ levels imply an increase in transpiration due to an increased foliage area but would also probably lead to a concurrent decline in transpiration by reducing stomatal conductance. Of the two the latter response is believed to be the preponderant factor at least for our model (Alkama, 2007). The net physiological effect of elevated $\mathrm{CO}_{2}$ concentration on transpiration could therefore be negative and result in a weakened hydrological cycle and an increasing aridity. 
Such an additional simulated decrease in soil moisture would not help to reduce model-data discrepancies but match climate change projections over the Mediterranean region for the 21st century (Giorgi and Lionello, 2008).

In this respect, the representation of physical processes such as ground hydrology may play a non negligible role. Local soil moisture changes can lead to variations in the regional intensity of the water cycle during the warm season when the convection precipitation regime intensifies. In our experiment, soils are drying out during the summer in response to the warmer ground temperatures. The representation of subsurface hydrological processes in the current land surface scheme used in the AGCM is indeed rather simple. The introduction of a groundwater component with an explicit representation of the water table in the land surface model would help to produce much wetter soil moisture profiles and more dry-period evapotranspiration (MiguezMacho et al., 2007), in a better agreement with the $\alpha$ data. In addition, it could reinforce the potential for regional recycling of water (Anyah et al., 2008). As the orography of the mid-Piacenzian was relatively flat, shallow water table conditions must have actually occured, leading to significantly wetter soil through the exchanges of water between the unsaturated soil and the underlying aquifer.

Lastly, water recycling also varies according to the vegetation characteristics. It is therefore worth taking into account a distribution of vegetation boundary conditions consistent with the precipitation rates and more generally, with the mid-Piacenzian climatology. This is the subject of our second experiment.

\subsection{Evaluating the consequences of vegetation changes on the mid-Piacenzian climate}

In response to the climate forcing of the first PLIOmodernveg run, ORCHIDEE simulates a potential vegetation distribution for the mid-Piacenzian which differs all the more from the one used in PLIO-modernveg since this latter corresponded to a modern (including anthropogenic) vegetation cover. Here we thus carry out a comparison of the impact of a forest-dominated vegetation against a human-dominated one, in which forests replace crop and pasture areas as well as expanses of bare soil, in the global warming context of the mid-Piacenzian. In this respect, it concurs with a number of recent studies on the relevance of taking into account the impact of land use change on surface climate (e.g. Kleidon, 2006; Bala et al., 2007; Davin et al., 2007).

\subsubsection{Near surface temperatures}

The effect of introducing a potential paleovegetation for the mid-Piacenzian on the simulated surface temperatures is found to be quite limited, as Jiang et al. (2005) demonstrated in their sensitivity study. In our study area, the vegetation feedback does not even have a strong impact on the regional scale, except during summer, when it contributes to a reduction of the seasonality of temperature, as in Haywood and Valdes (2006).

Despite the mean land surface temperature not being very sensitive to land cover change, our simulation results point out that the mid-Piacenzian forest spread results in a surface cooling in most of western Europe, compared to the PLIOmodernveg experiment. When considering alterations in the land cover, various competitive terms contribute to affect surface temperature: the radiative forcing due to change in albedo and water vapour and non-radiative processes, e.g. the alteration of turbulent exchanges of sensible and latent heat (Kleidon, 2006; Davin et al., 2007). In our model simulations, modifying the vegetated cover by roughly converting grasslands to forests has two main opposite effects on temperature. On the one hand, the general reduction in surface albedo results in an increased net surface solar absorption, which means warming. Anomalies of the annual mean surface albedo of a few percents are produced by the AGCM over the study area (Fig. 6c). On the other hand, converting grasslands to tree-type vegetation tends to increase the land surface evapotranspiration rates. This effect is especially relevant during the summer months in northwestern Europe, with evapotranspiration anomalies between the two mid-Piacenzian simulations reaching $250 \mathrm{~mm} / \mathrm{yr}$ (Fig. 6d). The subsequent increase in latent heat fluxes, of the order of a few tens of $\mathrm{W} / \mathrm{m}^{2}$ during summer, proportional to evaporation, explains the cooling of the near-surface atmosphere over land. The increase in latent heat cooling seems to outweigh the increase in surface solar radiation heating, meaning that the non-radiative processes dominate the summer climate response.

The evapotranspiration changes could also result in an increase in low-level cloudiness that would further cool the surface climate since cloud formation tends to limit the solar radiation income. Indeed, it has been shown that cloud feedbacks initiated by evapotranspiration changes may play a major role in determining the overall climatic impact of land cover change, in the context of deforestation over tropical regions (Bala et al., 2007). However, our simulation results do not suggest any increase in low-level cloudiness over the concerned areas nor any significant relationship between evapotranspiration and clouds changes. Thus, the impact of the cloud response on the energy balance of the climate system seems rather limited at such latitudes despite the globally warmer climate of the mid-Piacenzian as compared with today.

\subsubsection{Hydrological cycle}

Vegetation changes also modify the surface water balance. Our simulation results suggest a weakening of the hydrological cycle over land in the PLIO-paleoveg run compared with the PLIO-modernveg one, except during summer. 
As already observed in the PLIO-modernveg-CTRL comparison, the model is still particularly sensitive to large-scale atmospheric effects in the PLIO-paleoveg run. The reduction in winter large-scale precipitation is more pronounced in the latter run, which accounts for the deterioration of the modeldata comparison over land. The further weakening of the winds, which may be due to increased roughness length because of vegetation change, affects the large-scale transport of heat and moisture. Indeed, the two mid-Piacenzian simulations show noticeable differences in regional precipitation minus evaporation rates with a marked decrease of the net atmospheric moisture convergence over land. It means that biophysical effects of land-cover change are not only felt at regional scales but may also impact the general atmospheric circulation and give rise to remote climate changes through nonlinear feedbacks (Gedney and Valdes, 2000; Chase et al., 2000; Baidya Roy et al., 2003). These changes being more diffuse, their evaluation is all the more complicated at the local scale, where changes in precipitation result from a combined effect of local vegetation changes, as well as in remote locations, through the atmospheric pathway. This also applies to temperatures.

Besides, a strengthening of moist convective precipitation events, in frequency or intensity, is simulated in the PLIOpaleoveg run during summer over land and during winter over the ocean, as compared to the PLIO-modernveg experiment. This convective rainfall response is linked to an intensification of the evapotranspiration, and the associated increasing water vapour content in the atmosphere. Mean annual precipitation rates therefore increase over the North Atlantic. The enhancement of summer convective rainfall over land is nonetheless not sufficient to counterbalance the decrease of large-scale precipitation, which occurs over the rest of the year (Fig. 6b).

\subsubsection{Why do vegetation changes not really contribute to a more accurate simulation of the mid-Piacenzian climate, as compared to paleodata?}

To conclude, our simulations demonstrate a moderate vegetation impact on temperature extremes and hydrological cycle over Europe and the Mediterranean area but which does not improve the model-data comparison of our first run (Fig. 7).

Regarding our experimental design, the fact that the vegetation distribution we use for the PLIO-paleoveg run was produced by a model-driven climate means that biases inherent in the GCM simulation (e.g. physics, boundary conditions, $\mathrm{CO}_{2}$ levels) may lead to biases in the predicted vegetation (Cosgrove et al., 2002; Crucifix and Hewitt, 2005). It is therefore not unexpected that the vegetation distribution produced by ORCHIDEE does not completely match the vegetation reconstructions depicted by the pollen data. For instance, tropical trees may be simulated as a consequence of the too warm $T_{\text {cold }}$ or simply because the vegetation classi- fication used by the model is not as specific as the biome typology of pollen data.

Consequently unrealistic vegetation changes may drive inadequate perturbations in the atmosphere dynamics, which can therefore not contribute to improve the mid-Piacenzian climate simulation. It is nonetheless expected that such a deterioration of the climate signal is quite negligible as we show that the vegetation impact on climate is moderate in the European and Mediterranean mid-latitudes.

Furthermore, the climate-vegetation system could be sensitive to the initial distribution of vegetation (Claussen, 1994), as several stable states may exist by starting the iterative process from different initial conditions (Crowley and Baum, 1997). In our case, we have not tested whether we would obtain the same mid-Piacenzian vegetation starting from a vegetation different from the modern, such as the PRISM2 vegetation or a PNV estimate, which would have at least reintroduced forest rather than grassland to much of Europe.

We have also assumed that the largest vegetation change is obtained after the first iteration. As the resulting climate change appeared to be quite limited in the study area, i.e. the climatology given to ORCHIDEE is not very different from the one including changes made by the vegetation itself, significant vegetation alteration would probably not occur by extending further the iterative process.

Our field of analysis of past climate-vegetation characteristics is also partly limited by the geographic location of our study area, because vegetation change appears to have quite little influence on climate in the mid-latitude regions, resulting in not very significant results (Bala et al., 2007). Examination of high resolution simulations centred over regions located in the low or high latitudes could help to better capture past climate-vegetation feedbacks associated to the warmer climate of the mid-Piacenzian.

The incomplete simulation design can also be invoked, as it prevents all of the vegetation effects on climate from being effective. Running ORCHIDEE in dynamic mode, allowing climate and vegetation to come into equilibrium, would have improved the model-data comparison, as shown in Haywood and Valdes (2006), although improvements mainly applied in tropical regions. Furthermore, conversion of vegetation does not only affect the climate system through the surface-energy budget but also through the carbon cycle. Plant-climate interactions are sensitive to atmospheric $\mathrm{CO}_{2}$ concentration. For instance, water balance depends on vegetation growth conditions that are highly $\mathrm{CO}_{2}$-dependent. A poor representation of LAI and stomatal conductance has been shown to disturb the hydrologic cycle (Alkama, 2007). Therefore, it appears possible to improve model-data comparison in future simulations. This is actually also true for pollen-based climate reconstructions, which do not include either the vegetation dependence on high mid-Piacenzian atmospheric $\mathrm{CO}_{2}$ concentration and are calibrated for pollen originating from plants growing under modern $\mathrm{CO}_{2}$ levels. Also, as landscape 
dynamics does not only affect the climate system at local or regional scale but can also have significant global impacts by altering large-scale circulations, ocean feedbacks will need to be considered.

\section{Conclusions}

This paper presents the results of a high resolution modelling experiment of the mid-Piacenzian climate, focusing on western Europe and the areas surrounding the Mediterranean Sea. Our motivation was twofold: (1) to evaluate the simulated climatologies by comparing them to paleoclimatic reconstructions from pollen records from individual locations and (2) to assess in detail the effects of altered vegetation boundary conditions, in the context of a climate warmer than today.

We find that the AGCM results are consistent with the evidence of increased temperatures provided by the data. Simulation results further indicate that continental moisture levels were quite different from today. However, the poor comparison of model versus data as regards the annual precipitation field or the E/PE pattern raises the issue of the accuracy of the imposed boundary conditions data sets for the midPiacenzian, the representation of the internal physics of the model and the pollen interpretation.

In order to more rigorously address this problem, it is now necessary to carry out an intercomparison between climate models simulations of the mid-Piacenzian according to an uniform experimental design. Such a project is already underway as part of Plio-MIP (Pliocene Model Intercomparison Project) (Chandler et al., 2008; Haywood et al., 2009). This will allow to explore the range of variability of the models' responses to the mid-Piacenzian warming, and to explain the dispersion of the results in terms of differences in the physics or in the parametrization of physical processes. Our next step in modelling the mid-Piacenzian climate will involve the use of fully-coupled atmosphere-ocean-vegetation models under prescribed boundary conditions from the PRISM3D data set (Cronin et al., 2005; Dowsett et al., 2006, 2009a; Dowsett and Robinson, 2009b; Robinson et al., 2008; Robinson, in press; Salzmann et al., 2008; Dwyer and Chandler, 2009). This is essential in the exploration of the roles of the ocean circulation, the atmosphere and the land surface changes and their contribution to mid-Piacenzian global warmth.

Many sensitivity studies about each PRISM boundary condition, such as the test on the vegetation cover carried out in this paper, have already been achieved. On the basis of our modelling results, we show evidence of an influence of the vegetation cover on the regional climate; however, the inclusion of a more appropriate vegetation distribution produces few significant changes at the mid-latitudes investigated in this study. Further work regarding the description of the hydrological cycle and relative to its parametrization will help to better take into account the vegetation impact on climate.
Acknowledgements. We thank H. J. Dowsett and the PRISM group for kindly providing the PRISM2 digital data set, A. Laîné for discussion on storm-tracks, M.-N. Woillez for discussion on vegetation modelling, M. Clet-Pellerin, Z. Zheng, F. Diniz, W. H. Zagjwin and the Netherlands Geological Survey for the pollen data of La Londe, Saint-Isidore, Rio Maior and Susteren, respectively, and A. M. Haywood, H. J. Dowsett and an anonymous referee for useful comments on an earlier version of the manuscript.

This paper is a contribution to the "Environments and Ecosystems Dynamic of the Eurasian Neogene" (EEDEN) project of the European Science Foundation and to the ECLIPSE II INSU programme: "Quantification de l'impact des forçages climatiques/anthropiques passés et futurs sur les circulations dans le bassin de Paris", in partnership with ANDRA, EDF, GDF and IRSN. This is an ISEM contribution no. 2009-103.

Edited by: V. Brovkin

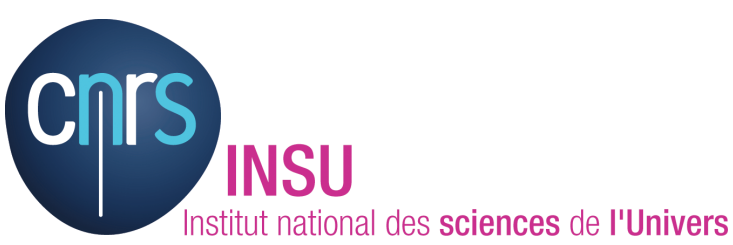

The publication of this article is financed by CNRS-INSU.

\section{References}

Alkama, R.: Interactions ruissellement-système climatique en climats froids et chauds, Ph.D. thesis, UPMC Univ. Paris 06, France, 2007.

Anyah, R., Weaver, C., Miguez-Macho, G., Fan, Y., and Robock, A.: Incorporating water table dynamics in climate modeling: 3. Simulated groundwater influence on coupled land-atmosphere variability, J. Geophys. Res., 113, D07103, doi:10.1029/2007JD009087, 2008.

Baidya Roy, S., Hurtt, G., Weaver, C., and Pacala, S.: Impact of historical land cover change on the July climate of the United States, J. Geophys. Res., 108, 4793, doi:10.1029/2003JD003565, 2003.

Bala, G., Caldeira, K., Wickett, M., Phillips, T., Lobell, D., Delire, C., and Mirin, A.: Combined climate and carbon-cycle effects of large-scale deforestation, P. Natl. Acad. Sci. USA, 104, 6550 6555, 2007.

Beaudouin, C., Suc, J.-P., Escarguel, G., Arnaud, M., and Charmasson, S.: The significance of pollen signal in present-day marine terrigenous sediments: the example of the Gulf of Lions (western Mediterranean Sea), Geobios, 40, 159-172, 2007.

Bessais, E. and Cravatte, J.: Les écosystèmes végétaux pliocènes de Catalogne méridionale, Variations latitudinales dans le domaine nord-ouest méditerranéen, Geobios, 21, 49-63, 1988.

Berggren, W., Kent, D., Swisher, C., and Aubry, M. P.: A revised Cenozoic geochronology and chronostratigraphy, in: Geochronology, time scales and global stratigraphic correlation, edited by: Berggren, W., Kent, D., Aubry, M. P., and Hardenbol, J., Society for Sedimentary Geology Special Publication, Tulsa, 129-212, 1995. 
Cambon, G., Suc, J.-P., Aloïsi, J. C., Giresse, P., Monaco, A., Touzani, A., Duzer, D., and Ferrier, J.: Modern pollen deposition in the Rhône delta area (lagoonal and marine sediments), France, Grana, 36, 105-113, 1997.

Chandler, M., Dowsett, H., and Haywood, A.: The PRISM model/data cooperative: mid-Pliocene data-model comparisons, PAGES News, 16, 24-25, 2008.

Chandler, M., Rind, D., and Thompson, R.: Joint investigations of the Middle Pliocene climate II: GISS GCM Northern Hemisphere results, Global Planet. Change, 9, 197-219, 1994.

Chase, T., Pielke Sr., R., Kittel, T., Nemani, R., and Running, S.: Simulated impacts of historical land cover changes on global climate in northern winter, Clim. Dynam., 16, 93-105, 2000.

Claussen, M.: On coupling global biome models with climate models, Climate Res., 4, 203-221, 1994.

Clet, M. and Huault, M. F.: Les dépôts lagunaires du Reuvérien dans les argiles de la Londe (Normandie, France), B. Assoc. Fr. Etud. Quaternaire, 4, 195-202, 1987.

Cosgrove, B., Barron, E., and Pollard, D.: A simple interactive vegetation model coupled to the GENESIS GCM, Global Planet. Change, 32, 253-278, 2002.

Cronin, T.: Pliocene shallow water paleoceanography of the North Atlantic ocean based on marine ostracods, Quaternary Sci. Rev., 10, 175-188, 1991.

Cronin, T., Dowsett, H., Dwyer, G., Baker, P., and Chandler, M.: Mid-Pliocene deep-sea bottom water temperatures based on ostracode Mg/Ca ratios, Mar. Micropaleontol., 54, 249-261, 2005.

Crowley, T.: Pliocene climates: the nature of the problem, Mar. Micropaleontol., 27, 3-12, 1996.

Crowley, T. and Baum, S.: Effect of vegetation on an ice-age climate model simulation, J. Geophys. Res., 102, 16463-16480, 1997.

Crucifix, M. and Hewitt, C.: Impact of vegetation changes on the dynamics of the atmosphere at the Last Glacial Maximum, Clim. Dynam., 25, 447-459, 2005.

Davin, E., de Noblet-Ducoudré, N., and Friedlingstein, P.: Impact of land cover change on surface climate: relevance of the radiative concept, Geophys. Res. Lett., 34, L13702, doi:10.1029/2007GL029678, 2007.

Diniz, F.: Apports de la palynologie à la connaissance du Pliocène portugais. Rio Maior: un bassin de référence pour l'histoire de la flore, de la végétation et du cimat de la façade atlantique de l'Europe méridionale, Habilitation thesis, Univ. Montpellier 2, France, 1984a.

Diniz, F.: Etude palynologique du bassin pliocène de Rio Maior, Paléobiologie Continentale, 14, 259-267, 1984b.

Dowsett, H.: The PRISM Palaeoclimate Reconstruction and Pliocene Sea-Surface Temperature, in: Deep-time perspectives on climate change: marrying the signal from computer models and biological proxies, edited by: Williams, M., Haywood, A., Gregory, F., and Schmidt, D., The Micropaleontological Society, Special Publications, The Geological Society, London, 459-480, 2007.

Dowsett, H., Barron, J., and Poore, R.: Middle Pliocene sea surface temperatures: a global reconstruction, Mar. Micropaleontol., 27, 13-26, 1996.

Dowsett, H., Barron, J., Poore, R., Thompson, R., Cronin, T., Ishman, S., and Willard, D.: Middle Pliocene paleoenvironmental reconstruction: PRISM2, US Geological Survey, Open file re- port, http://pubs.usgs.gov/openfile/of99-535, 99-535, 1999.

Dowsett, H., Chandler, M., Cronin, T., and Dwyer, G.: Middle Pliocene sea surface temperature variability, Paleoceanography, 20, PA2014, doi:10.1029/2005PA001133, 2005.

Dowsett, H., Chandler, M., and Robinson, M.: Surface temperatures of the Mid-Pliocene North Atlantic Ocean: implications for future climate, Philos. T. Roy. Soc. A, 367, 69-84, 2009a.

Dowsett, H. and Cronin, T.: Preface, Quaternary Sci. Rev., 10, v-vi, 1991.

Dowsett, H., Cronin, T., Poore, R., Thompson, R., Whatley, R., and Wood, A.: Micropaleontological evidence for increased meridional heat-transport in the North Atlantic Ocean during the Pliocene, Science, 258, 1133-1135, 1992.

Dowsett, H. and Robinson, M.: Mid-Pliocene equatorial Pacific sea surface temperature reconstructions: a multi-proxy perspective, Philos. T. Roy. Soc. A, 367, 109-125, 2009 b.

Dowsett, H., Robinson, M., Dwyer, G., Chandler, M., and Cronin, T.: PRISM 3 DOT1 Atlantic Basin Reconstruction, US Geological Survey Data Series, 189, 2006.

Dowsett, H., Thompson, R., Barron, J., Cronin, T., Fleming, R., Ishman, S., Poore, R., Willard, D., and Holtz, T.: Joint investigations of the Middle Pliocene climate I, PRISM paleoenvironmental reconstructions, Global Planet. Change, 9, 169-195, 1994.

Ducoudré, N., Laval, K., and Perrier, A.: SECHIBA, a new set of parameterizations of the hydrologic exchanges at the landatmosphere interface within the LMD atmospheric general circulation model, J. Climate, 6, 248-273, 1993.

Dwyer, G. and Chandler, M.: Mid-Pliocene sea-level and continental ice volume based on coupled benthic $\mathrm{Mg} / \mathrm{Ca}$ palaeotemperatures and oxygen isotopes, Philos. T. Roy. Soc. A, 367, 157-168, 2009.

Eady, E.: Long waves and cyclone waves, Tellus, 1, 33-52, 1994.

Fauquette, S., Guiot, J., and Suc, J.-P.: A method for climatic reconstruction of the Mediterranean Pliocene using pollen data, Palaeogeogr. Palaeocl., 144, 183-201, 1998a.

Fauquette, S., Quézel, P., Guiot, J., and Suc, J.-P.: Signification bioclimatique de taxons-guides du Pliocène méditerranéen, Geobios, 31, 151-169, 1998b.

Fauquette, S., Suc, J.-P., Guiot, J., Diniz, F., Feddi, N., Zheng, Z., Bessais, E., and Drivaliari, A.: Climate and biomes in the West Mediterranean area during the Pliocene, Palaeogeogr. Palaeocl., 152, 15-36, 1999.

Fauquette, S., Suc, J.-P., Jiménez-Moreno, G., Micheels, A., Jost, A., Favre, E., Bachiri-Taoufiq, N., Bertini, A., Clet-Pellerin, M., Diniz, F., Farjanel, G., Feddi, N., and Zheng, Z.: Latitudinal climatic gradients in Western European and Mediterranean regions from the Mid-Miocene ( $\sim 15 \mathrm{Ma})$ to the Mid-Pliocene ( $\sim 3.5 \mathrm{Ma})$ as quantified from pollen data, in: Deep-time perspectives on climate change: marrying the signal from computer models and biological proxies, edited by: Williams, M., Haywood, A., Gregory, F., and Schmidt, D., The Micropaleontological Society, Special Publications, The Geological Society, London, UK, 481502, 2007.

Favre, E.: Evolution de la végétation de l'Europe et du pourtour méditerranéen au Néogène dans les contextes climatique global et géographique régional. Approches statistiques et élaboration de cartes de végétation à partir des données polliniques, Ph.D. thesis, UCB Univ. Lyon 1, France, 262 pp., 2007. 
Gedney, N. and Valdes, P.: The effect of Amazonian deforestation on the Northern Hemisphere circulation and climate, Geophys. Res. Lett., 27, 3053-3056, 2000.

Giorgi, F. and Lionello, P.: 21st Climate change projections for the Mediterranean region, Global Planet. Change, 63, 90-104, 2000.

Haywood, A., Chandler, M., Valdes, P., Salzmann, U., Lunt, D., and Dowsett, H.: Comparison of Mid-Pliocene climate predictions produced by the HadAM3 and GCMAM3 General Circulation Models, Global Planet. Change, 66, 208-224, 2009.

Haywood, A., Sellwood, B., and Valdes, P.: Regional warming: Pliocene ( $3 \mathrm{Ma}$ ) paleoclimate of Europe and the Mediterranean, Geology, 28, 1063-1066, 2000b.

Haywood, A., Valdes, P., and Sellwood, B.: Global scale palaeoclimate reconstruction of the Middle Pliocene climate using the UKMO GCM: initial results, Global Planet. Change, 25, 239256, 2000a.

Haywood, A., Valdes, P., Sellwood, B., Kaplan, J., and Dowsett, H.: Modelling Middle Pliocene warm climates of the USA, Palaeontol. Electron., 4, 5, 21 pp., 2001.

Haywood, A. and Valdes, P.: Modelling Middle Pliocene warmth: contribution of atmosphere, oceans and cryosphere, Earth Planet. Sc. Lett., 218, 363-377, 2004.

Haywood, A. and Valdes, P.: Vegetation cover in a warmer world simulated using a dynamic global vegetation model for the MidPliocene, Palaeogeogr. Palaeocl., 237, 412-427, 2006.

Haywood, A., Valdes, P., and Peck, V.: A permanent El Niñolike state during the Pliocene?, Paleoceanography, 22, PA1213, doi:10.1029/2006PA001323, 2007.

Heusser, L.: Pollen distribution in marine sediments on the continental margin of northern California, Mar. Geol., 80, 131-147, 1988.

Hoskins, B. and Valdes, P.: On the existence of storm-tracks, J. Atmos. Sci., 47, 1854-1864, 1990.

Jansen, E., Overpeck, J., Briffa, K., Duplessy, J.-C., Joos, F., Masson-Delmotte, V., Olago, D., Otto-Bliesner, B., Peltier, W., Rahmstorf, S., Ramesh, R., Raynaud, D., Rind, D., Solomina, O., Villalba, R., and Zhang, D.: Palaeoclimate, in: Climate Change 2007: The Physical Science Basis, Contribution of Working Group I to the Fourth Assessment Report of the Intergovenmental Panel on Climate Change, edited by: Solomon, S., Qin, D., Manning, M., Chen, Z., Marquis, M., Averyt, K., Tignor, M., and Miller, H., Cambridge University Press, Cambridge and New York, 433-498, 2007.

Jiang, D., Wang, H., Ding, Z., Lang, X., and Drange, H.: Modeling the Middle Pliocene climate with a global atmospheric general circulation model, J. Geophy. Res., 110, D14107, doi:10.1029/2004JD005639, 2005.

Jost, A., Lunt, D., Kageyama, M., Abe-Ouchi, A., Peyron, O., Valdes, P., and Ramstein, G.: High-resolution simulations of the last glacial maximum climate over Europe: a solution to discrepancies with continental palaeoclimatic reconstructions?, Clim. Dynam., 24, 577-590, 2005.

Kageyama, M., Combourieu-Nebout, N., Sepulchre, P., Peyron, O., Krinner, G., Ramstein, G., and Cazet, J.-P.: The Last Glacial Maximum and Heinrich Event 1 in terms of climate and vegetation around the Alborean Sea: a preliminary model-data comparison, C. R. Geosci., 337, 983-992, 2005.

Kageyama, M., Laîné, A., Abe-Ouchi, A., Braconnot, P., Cortijo, E., Crucifix, M., de Vernal, A., Guiot, J., Hewitt, C., Kitoh, A.,
Kucera, M., Marti, O., Ohgaito, R., Otto-Bliesner, B., Peltier, W., Rosell-Melé, A., Vettoretti, G., Weber, S., Yu, Y., and MARGO Project Members: Last Glacial Maximum temperatures over the North Atlantic, Europe and Western Siberia: a comparison between PMIP models, MARGO sea-surface temperatures and pollen-based reconstructions, Quaternary. Sci. Rev., 25, 2082 2102, 2006.

Kleidon, A.: The climate sensitivity to human appropriation of vegetation productivity and its thermodynamic characterization, Global Planet. Change, 54, 109-127, 2006.

Krinner, G., Viovy, N., de Noblet-Ducoudré, N., Ogée, J., Polcher, J., Friedlingstein, P., Ciais, P., Sitch, S., and Prentice, I.: A dynamic global vegetation model for studies of the coupled atmosphere-biosphere system, Global Biogeochem. Cy., 19, GB1015, doi:10.1029/2003GB002199, 2005.

Kürschner, W., van der Burgh, J., Visscher, H., and Dilcher, D.: Oak leaves as biosensors of late Neogene and early Pleistocene paleoatmospheric $\mathrm{CO}_{2}$ concentrations, Mar. Micropaleontol., 27, 299-312, 1996.

Laîné, A., Kageyama, M., Salas-Mélia, D., Ramstein, G., Planton, S., Denvil, S., and Tyteca, S.: An energetics study of wintertime Northern Hemisphere storm tracks under $4 \mathrm{CO}_{2}$ conditions in two ocean-atmosphere coupled models, J. Climate, 22, 819839, 2009.

Leroy, S., Wrenn, J. H., and Suc, J.-P.: Global setting to comparative charts of regional events, in: The Pliocene: Time of change, edited by: Wrenn, J. H., Suc, J.-P., and Leroy, S., American Association of Stratigraphic Palynologists Foundation, 1-12, 1998.

Levis, S., Foley, J., and Pollard, D.: Large-scale vegetation feedbacks on a doubled $\mathrm{CO}_{2}$ climate, J. Climate, 13, 1313-1325, 2000 .

Li, L., Bozec, A., Somot, S., Béranger, K., Bouruet-Aubertot, P., Sevault, F., and Crépon, M.: Regional atmospheric, marine processes and climate modelling, in: Mediterranean Climate Variability, edited by: Lionello, P., Malanotte, P., and Boscolo, R., Elsevier B. V., Amsterdam, The Netherlands, 373-397, 2006.

Li, L. and Conil, S.: Transient response of an atmospheric GCM to North Atlantic SST anomalies, J. Climate, 16, 3993-3998, 2003.

Lionello, P., Malanotte-Rizzoli, P., Alpert, P., Artale, V., Boscolo, R., Li, L., Luterbacher, J., May, W., Trigo, R., Tsimplis, M., Ulbrich, U., and Xoplaki, E.: MedCLIVAR: Mediterranean CLImate VARiability, CLIVAR Exchanges, 11, 3-5, 2006.

Lunt, D., Foster, G., Haywood, A., and Stone, E.: Late Pliocene Greenland glaciation controlled by a decline in atmospheric $\mathrm{CO}_{2}$ levels, Nature, 454, 1102-1106, 2008a.

Lunt, D., Haywood, A., Foster, G., and Stone, E.: The Arctic cryosphere in the Mid-Pliocene and the future, Philos. T. Roy. Soc. A, 367, 49-67, 2009.

Lunt, D., Valdes, P., Haywood, A., and Rutt, I.: Closure of the Panama Seaway during the Pliocene, implications for climate and Northern Hemisphere glaciation, Clim. Dynam., 30, 1-18, $2008 b$.

Marti, O., Braconnot, P., Bellier, J., Benshila, R., Bony, S., Brockmann, P., Cadule, P., Caubel, A., Denvil, S., Dufresne, J. L., Fairhead, L., Filiberti, M. A., Foujols, M. A., Fichefet, T., Friedlingstein, P., Goosse, H., Grandpeix, J. Y., Hourdin, F., Krinner, G., Lévy, C., Madec, G., Musat, I., de Noblet, N., Polcher, J., and Talandier, C.: The new IPSL climate system model: IPSL-CM4, Note du Pôle de Modélisation 26, Institut Pierre Simon Laplace, 
Paris, France, 84 pp., 2005.

Meehl, G., Stocker, T., Collins, W., Friedlingstein, P., Gaye, A., Gregory, J., Kitoh, A., Knutti, R., Murphy, J., Noda, A., Raper, S., Watterson, I., Weaver, A., and Zhao, Z.-C.: Global climate projections, in: Climate Change 2007: The Physical Science Basis, Contribution of Working Group I to the Fourth Assessment Report of the Intergovenmental Panel on Climate Change, edited by: Solomon, S., Qin, D., Manning, M., Chen, Z., Marquis, M., Averyt, K., Tignor, M., and Miller, H., Cambridge University Press, Cambridge and New York, 747-846, 2007.

Miguez-Macho, G., Fan, Y., Weaver, C., Walko, R., and Robock, A.: Incorporating water table dynamics in climate modeling: 2. Formulation, validation, and soil moisture simulation, J. Geophys. Res., 112, D13108, doi:10.1029/2006JD008112, 2007.

Molnar, P. and Cane, M.: El Niño's tropical climate and teleconnections as a blue-print for pre-Ice Age climates, Paleoceanography, 17, 1021, doi:10.1029/2001PA000663, 2002.

New, M., Hulme, M., and Jones, P.: Representing twentieth-century space-time climate variability: I. Development of a 1961-90 mean monthly climatology, J. Climate, 12, 829-856, 2002.

de Noblet, N.: Modelling late-Quaternary palaeoclimates and palaeobiomes, in: Past and future rapid environmental changes: The spatial and evolutionary responses of terrestrial biota, edited by: Huntley, B., Cramer, W., Morgan, A., Prentice, H., and Allen, J., NATO ASI Series I 47, Springer-Verlag, Berlin Heidelberg, Germany, 523 pp., 1997.

Pearson, P. and Palmer, M.: Atmospheric carbon dioxide concentrations over the past 60 million years, Nature, 406, 695-699, 2000.

Piao, S., Friedlingstein, P., Ciais, P., de Noblet-Ducoudré, N., Labat, D., and Zaehle, S.: Changes in climate and land use have a larger direct impact than rising $\mathrm{CO}_{2}$ on global river runoff trends, $\mathrm{P}$. Natl. Acad. Sci. USA, 104, 15242-15247, 2007.

Pinot, S., Ramstein, G., Harrison, S., Prentice, C., Guiot, J., Stute, M., and Joussaume, S.: Tropical paleoclimates at the Last Glacial Maximum: comparison of Paleoclimate Modeling Intercomparison Project (PMIP simulations and paleodata, Clim. Dynam, 15, 857-874, 1999.

Poore, R. and Sloan, L.: Climates and climate variability of the Pliocene, Mar. Micropaleontol., 27, 1-2, 1996.

Ramstein, G., Kageyama, M., Guiot, J., Wu, H., Hély, C., Krinner, G., and Brewer, S.: How cold was Europe at the Last Glacial Maximum? A synthesis of the progress achieved since the first PMIP model-data comparison, Clim. Past, 3, 331-339, 2007, http://www.clim-past.net/3/331/2007/.

Raymo, M., Grant, B., Horowitz, M., and Rau, G.: Mid-Pliocene warmth: stronger greenhouse and stronger conveyor, Mar. Micropaleontol., 27, 313-326, 1996.

Rind, D. and Chandler, M.: Increased ocean heat transports and warmer climate, J. Geophys. Res., 96, 7437-7461, 1991.

Robinson, M., Dowsett, H., Dwyer, G., and Lawrence, K.: Reevaluation of mid-Pliocene North Atlantic sea surface temperatures, Paleoceanography, 23, PA3213, doi:10.1029/2008PA001608, 2008.

Robinson, M.: New quantitative evidence of extreme warmth in the Pliocene Arctic, Stratigraphy, in press, 2009.

Salzmann, U., Haywood, A., and Lunt, D.: The past is a guide to the future? Comparing Middle Pliocene vegetation with predicted biome distributions for the twenty-first century, Philos. T. Roy.
Soc. A, 367, 189-204, 2009.

Salzmann, U., Haywood, A., Lunt, D., Valdes, P., and Hill, D.: A new global biome reconstruction and data-model comparison for the Middle Pliocene, Global Ecol. Biogeogr., 17, 432-447, 2008.

Sepulchre, P., Ramstein, G., Kageyama, M., Vanhaeren, M., Krinner, G., Sánchez-Goñi, M. F., and d'Errico, F.: H4 abrupt event and late Neanderthal presence in Iberia, Earth Planet. Sci. Lett., 258, 283-292, 2007.

Sitch, S., Smith, B., Prentice, C., Arneth, A., Bondeau, A., Cramer, W., Kaplan, J., Levis, S., Lucht, W., Sykes, M., Thonicke, K., and Venevsky, S.: Evaluation of ecosystem dynamics, plant geography and terrestrial carbon cycling in the LPJ dynamic vegetation model, Global Change Biol., 9, 161-185, 2003.

Sloan, L., Crowley, T. and Pollard, D.: Modeling of Middle Pliocene climate with the NCAR GENESIS general circulation model, Mar. Micropaleontol., 27, 51-61, 1996.

Somot, S., Sevault, F., Déqué, M., and Crépon, M.: 21st century climate change scenario for the Mediterranean using a coupled atmosphere-ocean regional climate model, Global Planet. Change, 63, 112-126, 2008.

St. John, K. E. K. and Krissek, L. A.: The Late Miocene to Pleistocene ice-rafting history of southeast Greenland, Boreas, 31, 28-35, 2002.

Sterling, S. and Ducharne, A.: Comprehensive data set of global land cover change for land surface model applications, Global Biogeochem. Cy., 22, GB3017, doi:10.1029/2007GB002959, 2008.

Suc, J.-P.: Distribution latitudinale et étagement des associations végétales au Cénozoïque supérieur dans l'aire ouestméditerranéenne, Bull. Soc. Géol. France, 8, 541-550, 1989.

Suc, J.-P. and Cravatte, J.: Etude palynologique du Pliocène de Catalogne (Nord-est de l'Espagne), Palobiol. Cont., 13, 1-31, 1982.

Suc, J.-P., Bertini, A., Combourieu-Nebout, N., Diniz, F., Leroy, S., Russo-Ermolli, E., Zheng, Z., Bessais, E., and Ferrier, J.: Structure of West Mediterranean and climate since 5.3 Ma, Acta Zoologica Cracovia, 38, 3-16, 1995a.

Suc, J.-P., Diniz, F., Leroy, S., Poumot, C., Bertini, A., Dupont, L., Clet, M., Bessais, E., Zheng, Z., Fauquette, S., and Ferrier, J.: Zanclean ( $\sim$ Brunssumian) to early Piacenzian ( $\sim$ earlymidlle Reuverian) climate from $4^{\circ}$ to $54^{\circ}$ north latitude (West Africa, West Europe and West Mediterranean areas), Meded. Rijks Geol. Dienst, 52, 43-56, 1995b.

Suc, J.-P., Fauquette, S., Bessedik, M., Bertini, A., Zheng, Z., Clauzon, G., Suballyova, D., Diniz, F., Quézel, P., Feddi, N., Clet, M., Bessais, E., Bachiri Taoufiq, N., Méon, H., and CombourieuNebout, N.: Neogene vegetation changes in West European and West circum-Mediterranean areas, in: Hominid Evolution and Climate in Europe, 1, Climatic and Environmental Change in the Neogene of Europe, edited by: Agusti, J., Rook, L., and Andrews, P., Cambridge University Press, Cambridge, UK, 370$385,1999$.

Taylor, K., Williamson, D., and Zwiers, F.: AMIP II sea surface temperature and sea ice concentration boundary conditions, Lawrence Livermore National laboratory, Open file report, http://www-pcmdi.llnl.gov/projects/amip/AMIP2EXPDSN/ BCS/amip2bcs.php, 2001.

van Dam, J. A.: Geographic and temporal patterns in the late Neogene (12-3 Ma) aridification of Europe: The use of small mammals as paleoprecipitation proxies, Palaeogeogr. Palaeocl., 238, 
190-218, 2006.

Wang, C. W.: The Forest of China (with a survey of grassland and desert vegetation), Maria Moors Cabot Foundation, Harvard University, 313 pp., 1961.

Williams, M., Haywood, A., Hillenbrand, C., and Wilkinson, I.: Efficacy of $\delta^{18} \mathrm{O}$ data from Pliocene planktonic foraminifer calcite for spatial sea surface temperature reconstruction: comparison with a fully coupled ocean-atmosphere GCM and fossil assemblage data for the mid-Pliocene, Geol. Mag., 142, 399-417, 2005.

Wu, H., Guiot, J., Brewer, S., and Guo, Z.: Climatic changes in Eurasia and Africa at the last glacial maximum and midHolocene: reconstruction from pollen data using inverse vegetation modelling, Clim. Dynam., 29, 211-229, 2007.

Zachos, J., Pagani, M., Sloan, L., Thomas, E., and Billups, K.: Trends, rhythms, and aberrations in global climate $65 \mathrm{Ma}$ to present, Science, 292, 686-693, 2001.
Zachos, J., Dickens, G., and Zeebe, R.: An early Cenozoic perspective on greenhouse warming and carbon-cycle dynamics, Nature, 451, 279-283, 2008.

Zagwijn, W.: Aspects of the Pliocene and early Pleistocene vegetation in the Netherlands, Mededelingen van de Geologische Stichting, 3, 1-78, 1960.

Zheng, Z.: Végétations et climats néogènes des Alpes maritimes franco-italiennes d'après les données de l'analyse palynologique, Paléobiol. Cont., 17, 217-244, 1990.

Zhou, T.-J. and Li, Z.-X.: Simulation of the East Asian Summer Monsoon using a variable resolution atmopsheric GCM, Clim. Dynam., 19, 167-180, 2002. 